\title{
Luxembourg: Article IV Consultation-Staff Report; Public Information Notice on the Executive Board Discussion; and Statement by the Executive Director for Luxembourg
}

Under Article IV of the IMF's Articles of Agreement, the IMF holds bilateral discussions with members, usually every year. In the context of the 2010 Article IV consultation with Luxembourg, the following documents have been released and are included in this package:

- The staff report for the 2010 Article IV consultation, prepared by a staff team of the IMF, following discussions that ended on April 20, 2010, with the officials of Luxembourg on economic developments and policies. Based on information available at the time of these discussions, the staff report was completed on May 12, 2010. The views expressed in the staff report are those of the staff team and do not necessarily reflect the views of the Executive Board of the IMF.

- $\quad$ A Public Information Notice (PIN) summarizing the views of the Executive Board as expressed during its May 28, 2010 discussion of the staff report that concluded the Article IV consultation.

- $\quad$ A statement by the Executive Director for Luxembourg.

The policy of publication of staff reports and other documents allows for the deletion of market-sensitive information.

\author{
Copies of this report are available to the public from \\ International Monetary Fund • Publication Services \\ $70019^{\text {th }}$ Street, N.W. • Washington, D.C. 20431 \\ Telephone: (202) 623-7430 • Telefax: (202) 623-7201 \\ E-mail: publications@imf.org Internet: http://www.imf.org
}

\section{International Monetary Fund Washington, D.C.}


INTERNATIONAL MONETARY FUND

\section{LUXEMBOURG}

\section{Staff Report for the 2010 Article IV Consultation}

Prepared by the Staff Representatives for the 2010 Consultation with Luxembourg

Approved by Ajai Chopra and Thomas Dorsey

May 12, 2010

- Mission. Discussions (April 7-19, 2010) were conducted by Messrs. Hoffmaister (Head), Vázquez and Vacher (all EUR). Staff met with Economy Minister Jeannot Krecké, Central Bank Governor Yves Mersch, other senior officials, and private sector representatives. Mr. Mevis (OED) participated in the policy discussions.

- $\quad$ Previous consultations. In recent years, there has been broad agreement between the authorities and staff on macroeconomic policies. At the conclusion of the 2009 Article IV Consultation, Directors commended the authorities for successfully dealing with problem banks. They emphasized the importance of maintaining financial stability and supported the authorities' actions to strengthen the supervisory and regulatory frameworks. Directors also supported the fiscal stimulus in response to the crisis and stressed the need to implement far-reaching reforms to the pension system to ensure the long-term sustainability of public finances.

- Exchange system. Luxembourg is a member of the euro area and has accepted the obligations under Article VIII, Sections 2-4.

- $\quad$ Statistical issues. Luxembourg has subscribed to the Fund's SDDS, and economic data are adequate for surveillance.

- $\quad$ FSAP Update. Luxembourg has requested an FSAP Update, which is expected to take place in the second half of 2010. 


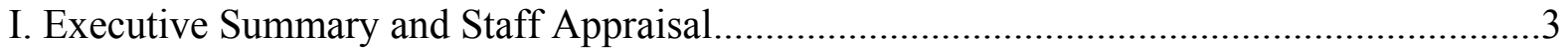

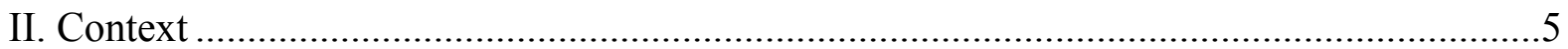

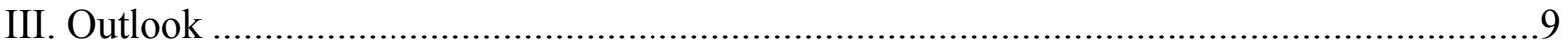

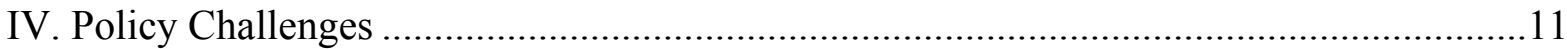

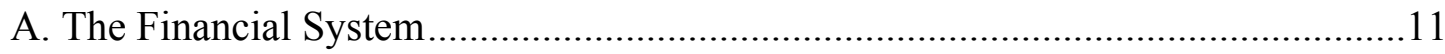

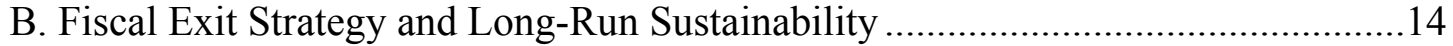

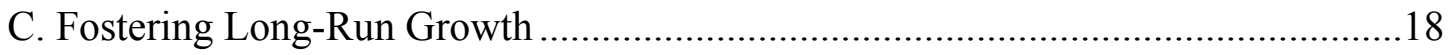

Figures

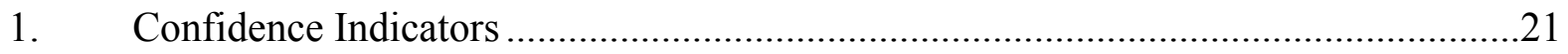

2. High Frequency Financial Indicators...................................................................22

3. Aggregate Banking Sector Assets and Funding.................................................23

Tables

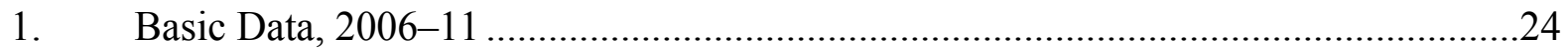

2. General Government Operations, 2006-14 .......................................................25

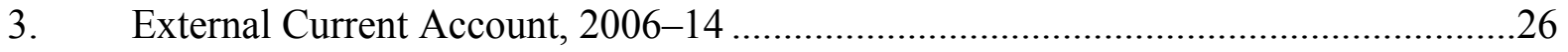

4. Financial Soundness Indicators, 2005-09..............................................................27

\section{Text Boxes}

1. Competitiveness ............................................................................................... 7

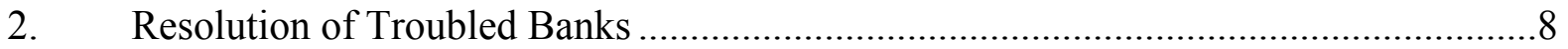

3. Impact of Age-Related Expenditures on Public Finances ...................................... 17 


\section{Executive SUMmary AND Staff APPRAisal}

1. The global financial crisis delivered a severe shock to Luxembourg's exceptionally open economy and internationally-integrated financial center. Private investment plummeted and consumption weakened in the face of slowing employment growth. At the height of the crisis, Luxembourg's sizeable investment fund industry endured substantial redemptions and its foreign-subsidiary dominated banking system experienced a sharp drop in its aggregate balance sheet as well as in its off-balance sheet positions. As a result, the economy contracted by $3 \frac{1}{2}$ percent in 2009 .

2. Still, a prompt and aggressive policy response safeguarded the financial sector and mitigated adverse economic effects. The authorities' decisive actions early on limited potential spillover effects. A five-fold increase in the deposit guarantee, combined with the ECB's emergency liquidity provision, served to restore confidence in the financial sector. In addition, Luxembourg's enviable fiscal position at the outset of the crisis enabled fiscal policy to provide substantial support to the economy, including by boosting social transfers to soften the impact on the labor force and protect household income.

\section{After navigating through its worst performance in 30 years, Luxembourg's} economy has since stabilized. No bank rescues were required in 2009 and investment fund assets have rebounded to close to their pre-crisis peak. Thanks also to developments in neighboring countries, growth resumed early in the second half of 2009 and labor markets showed initial signs of recovery.

4. The global financial crisis, nonetheless, will have lasting effects on the economy. Systemic financial risks have abated in line with global developments and bank deleveraging has remained orderly and gradual. A number of institutions have continued unwinding noncore activities and refocusing their business models and improving efficiency, and declines in financial sector employment have been gradual. Despite ongoing bank restructuring, the financial center's business model has not changed substantially. Banks continue to have large and concentrated cross-border positions with foreign parent banks. Lingering uncertainty in global financial markets and potential knock-on effects on neighboring countries as well as ongoing international regulatory initiatives on liquidity and leverage weigh on Luxembourg's growth prospects.

\section{The crisis has revealed the need to strengthen key aspects of the prudential and} supervisory framework. The EU incorporation and business orientation of the majority of parent banks and long-standing collaboration between local and home country supervisors facilitated responding to the crisis. But there is need to strengthen regulations and supervisory focus on liquidity and credit risks. Regarding the former, sharpening the focus on liquidity risks originating from large interbank and notably intra-group exposures will require revamping the prudential framework governing quantitative aspects of liquidity risk and bank reporting processes. In addition, continued cooperation between the Banque Centrale du 
Luxembourg (BCL) and the Commission de Surveillance du Secteur Financier (CSSF) in monitoring and assessing liquidity risk will be essential and can benefit from the support of a formal agreement. Regarding tail credit risks, there is a need to further step up efforts in assessing banks' credit risk management practices and, when needed, taking action to ensure the adequacy of bank capital. In this connection, promptly transposing forthcoming EU directives and Basel Committee of Banking Supervision recommendations on the level and quality of capital buffers and potential restrictions on leverage will be essential.

6. Improvements in the supervisory process and regulatory environment should go hand in hand with increased reliance on joint work with home supervisors. Given the cross-border nature of Luxembourg's banking groups, the importance of strengthening collaboration with fellow supervisors and actively engaging in the work of relevant supervisory colleges cannot be overstated. The CSSF's participation in these colleges provides a new avenue to intensify collaboration with home supervisors and further strengthen supervision.

7. In addition, the crisis highlighted the necessity of establishing formal mechanisms for cross-border bank resolution and burden sharing. Given the prevalence of foreign-owned subsidiaries, the effectiveness of resolution and crisis management efforts in response to systemic events hinges on an active coordination with home-country authorities. The formalization of agreements on burden sharing, the harmonization across crisis resolution frameworks, and the development of consistent mechanisms for crisis management and bank resolution extend beyond the domain of Luxembourg's authorities. Given the critical importance of these matters, Luxembourg's continued active engagement in these discussions is paramount.

8. While fiscal support to the economy is appropriate in the short term, the 2011 budget must set the stage for sustainable fiscal consolidation. Even though the economy is projected to strengthen, on unchanged policies, the fiscal deficit is poised to remain above or close to the Maastricht limit. Still, consistent with the Stability and Growth Pact (SGP) update, the authorities are committed to begin consolidation in 2011 and reestablish a balance by 2014 . In this regard, the recently announced 2011-12 consolidation measures to rationalize current expenditures and share the burden of the adjustment across social partners are welcome. As the authorities acknowledge, achieving a balance in 2014 will require additional measures and these should focus more directly on current expenditure. Fiscal consolidation can be also supported by a medium-term framework to facilitate expenditure review and prioritization and provide a tool for early detection of adjustment needs.

9. Enduring fiscal stability requires, nonetheless, substantive pension reform. Gains in life expectancy combined with generous benefits will place considerable pressure on Luxembourg's pay-as-you-go pension system. Reforms should aim at gradually increasing the effective and statutory retirement age including by eliminating design features that encourage early retirement and improving the alignment of benefits and contributions. There 
will also be a need to rein in the rate of increase of existing old-age pensions. Introducing periodic reviews of the social security's financial health would enable timely adjustments to reflect economic and demographic developments. The global financial crisis' adverse impact on employment growth prospects and social security contributions from cross-border workers has heightened the urgency of putting in place reforms early.

\section{Looking forward, the resilience of Luxembourg's economy will depend on} cultivating its comparative advantage in high value added niche activities. Years of economic boom had masked the need for continued improvements in productivity. But global deleveraging, the restructuring of the global financial landscape, and the international push to harmonize taxation and limit bank secrecy will challenge some segments of the financial center. In this regard, the authorities' proposal to adjust the backward-looking wage indexation mechanism would represent an essential step to limit its adverse impact on competitiveness. Further adjustments will be needed to modernize wage-setting mechanisms with a view of eliminating automatic indexation over time. In addition, gains in productivity can be generated by a business friendly environment supportive of investment in research and development and the acquisition of new skills by the labor force. This can help alleviate labor skill mismatches, but determined efforts will be needed to safeguard the advantages accumulated through years of experience as a financial center, curtail unemployment among residents and sustain Luxembourg's prosperity.

\section{It is recommended that the Article IV consultation remain on a 12-month cycle.}

\section{CONTEXT}

\section{Luxembourg's large financial system} plays a central role in the economy. The financial system consists of a sizeable investment fund industry-Europe's largest with a portfolio equivalent to 50 times GDP — and a vast outwardoriented banking industry with 150 banks and an aggregate balance sheet of almost 30 times GDP. The investment fund and banking industries are closely intertwined, channeling large cross-border investment flows in the EU, mainly through international interbank and money markets. ${ }^{1}$ Interconnections between banks and their sponsored investment funds are diverse and result

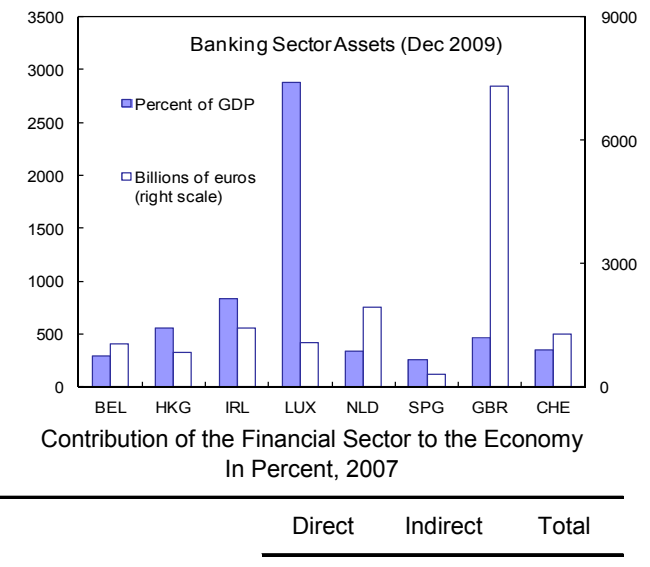

\begin{tabular}{llll} 
Value Added & 39 & 6 & 45 \\
Employment & 13 & 8 & 21 \\
Tax Revenues & 29 & 5 & 34 \\
\hline
\end{tabular}

Source: Codeplafi; and Deloitte

${ }^{1}$ Luxembourg-based banks maintain half of their assets (about ten times GDP) in the interbank market, mainly with their parent banks abroad. They are net providers of liquidity to parent banks and also play a central role in the recycling of liquidity from the investment fund industry to the EU banking systems. 
in sizeable cross sector exposures. The financial sector's dynamism reflects a number of factors, including early transposition of the EU passport for investment funds, a multilingual and skilled labor force, an efficient regulatory environment, low taxation, and bank privacy legislation. ${ }^{2}$ The financial system has been the main driver of economic growth in the past two decades and its competitiveness has been central to the economy (Box 1).

\section{The global financial crisis posed a severe test to Luxembourg's financial sector.}

Luxembourg's investment fund industry endured substantial redemptions totaling about three times GDP. In addition, Luxembourg's foreign-subsidiary dominated banking sector has experienced a 20 percent contraction in its aggregate balance sheet (equivalent to four times GDP) as a result of deleveraging and restructuring. Banks have also seen a 30 percent drop in their off-balance sheet positions as assets under management dwindled. At the height of the global financial turmoil, several banks experienced severe liquidity shortages, the systemically important subsidiaries of Dexia and Fortis succumbed to pressure from a severe loss of investor confidence at the group level and

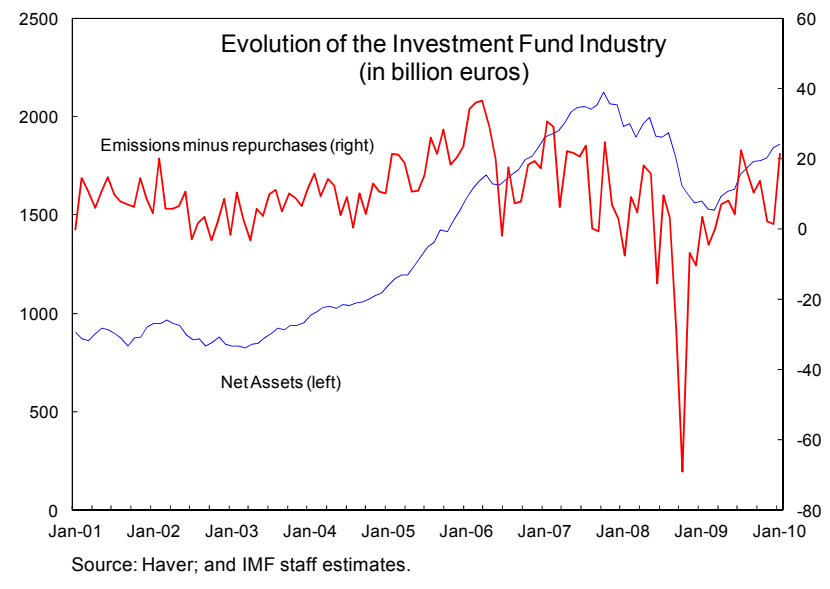
three Icelandic subsidiaries failed (Box 2). The crisis revealed weaknesses in risk management practices in the banking system, unwarranted liquidity transformation by some institutions and gaps in the prudential framework and financial sector supervision, particularly regarding liquidity and credit risks.

\section{The authorities' aggressive} policy response limited the impact of the crisis. Decisive action in tackling troubled banks, in concert with the authorities of Belgium, France, and the Netherlands, quelled potential spillover effects and maintained the financial center's stability. In addition, a five-fold

\begin{tabular}{|c|c|c|c|c|}
\hline & \multicolumn{4}{|c|}{ Fiscal Impact (percent of GDP) } \\
\hline & $\begin{array}{c}2009 \\
\text { (Art. IV) }\end{array}$ & $\begin{array}{c}2009 \\
\text { (actual) }\end{array}$ & $\begin{array}{l}2009 \\
\text { (diff.) }\end{array}$ & $\begin{array}{c}2010 \\
\text { (budget) }\end{array}$ \\
\hline Expenditure side & 1.5 & 0.9 & -0.5 & 0.9 \\
\hline Transfers to households & 0.7 & 0.5 & -0.2 & 0.3 \\
\hline Transfers to business & 0.1 & 0.1 & 0.0 & 0.1 \\
\hline Public investment $1 /$ & 0.6 & 0.3 & -0.3 & 0.5 \\
\hline Revenue side & -1.5 & -1.5 & 0.0 & -0.5 \\
\hline Personal income taxes & -1.2 & -1.2 & 0.0 & 0.0 \\
\hline Indexation of the tax brackets & -0.9 & -0.9 & 0.0 & 0.0 \\
\hline Increased tax credits & -0.3 & -0.3 & 0.0 & 0.0 \\
\hline Corporate income taxes & -0.3 & -0.3 & 0.0 & -0.5 \\
\hline Abolition of the capital contribution tax & -0.3 & -0.3 & 0.0 & 0.0 \\
\hline CIT rate reduction (from 22 to 21 percer & 0.0 & 0.0 & 0.0 & -0.5 \\
\hline Total fiscal Impact & 3.0 & 2.4 & -0.5 & 1.4 \\
\hline memo: & & & & \\
\hline Public sector balance & -3.3 & -0.7 & 2.6 & -3.9 \\
\hline GDP growth & -5.3 & -3.4 & 1.9 & 3.0 \\
\hline
\end{tabular}

\footnotetext{
${ }^{2}$ Taxes on investment funds are based on the volume of the portfolios under management, with rates varying between $0-5$ percent depending on the size and type of fund. The average effective tax rate is close to the lower end of the range as money market funds - subject to tax rates below 1 percent - account for the bulk of funds. Capital gains on investments held for at least two years are not subject to taxes in Luxembourg. But tax agreements with other jurisdictions result in taxes being owed in the foreign investor's country of residence.
} 


\section{Box 1. Competitiveness}

Since 2000, REER measures have exhibited an appreciation trend. Labor hoarding explains part of the strong increase in unit labor costs since 2007. Nonetheless, unit labor costs have exhibited sharper increases over time compared to Luxembourg's main competitors, reflecting slower productivity gains and higher wages - as a rapidly expanding financial sector pressured labor markets. Since 2005, the manufacturing sector's competitiveness has also deteriorated as unit labor costs have increased. This has hurt Luxembourg's EU export market share since 2006, even though its share of world merchandise exports remains stable. While Luxembourg boasts the highest productivity in the EU, its productivity measurement tends to be biased by the relative importance of the financial sector-with inherent difficulties in calculating and interpreting estimates of financial sector unit labor costs.
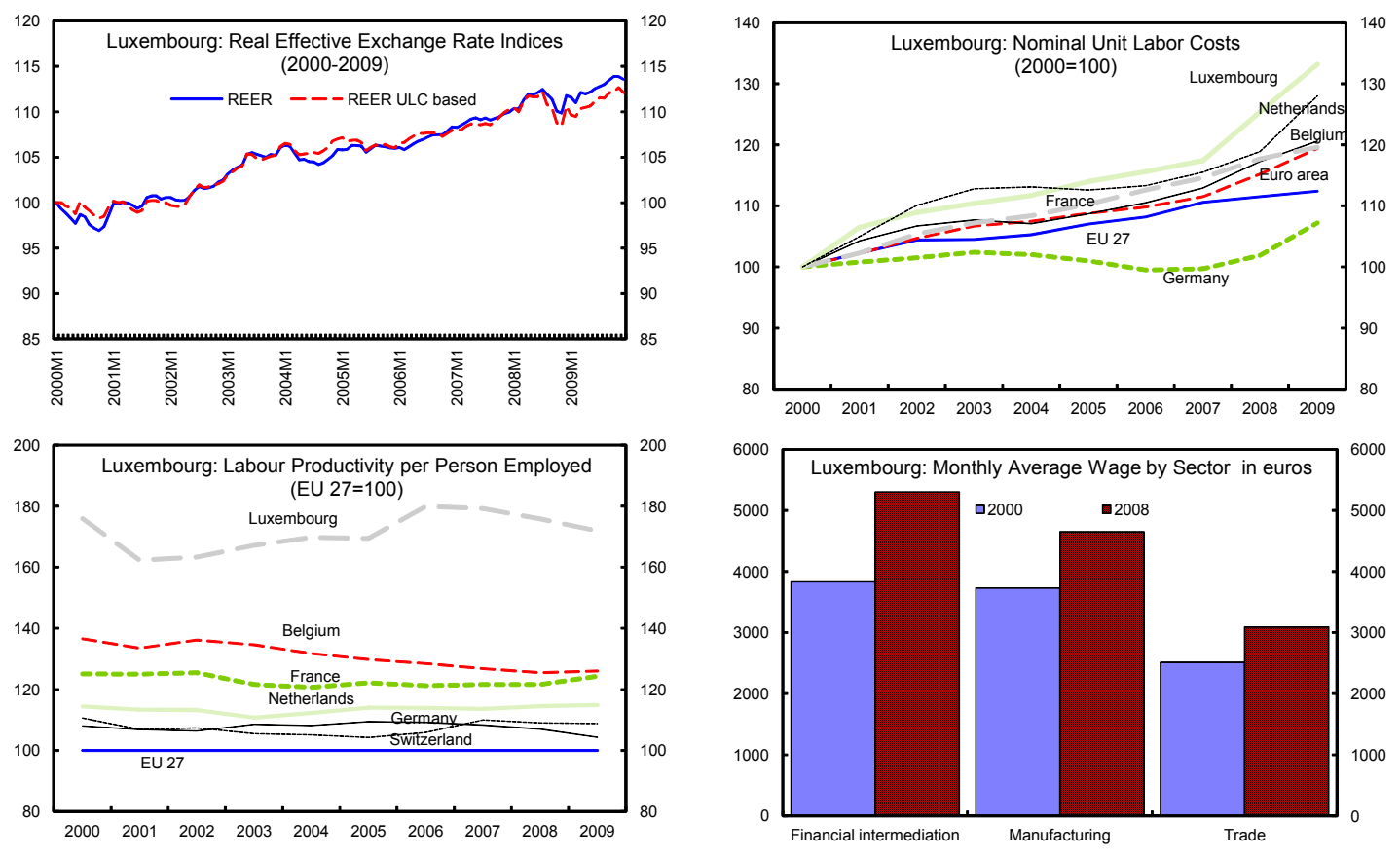

Source: Eurostat, Statec.

Overall, CGER estimates do not point to a competitiveness gap but the assessment is complicated by the large size of the financial sector. The global financial crisis and its impact on the determinants of the equilibrium real exchange rate - particularly on global asset returns and growth prospects-have meant that there is a higher than usual degree of uncertainty in assessing the equilibrium level of the exchange rate.

Luxembourg's medium-term balance of payments projections have larger than usual forecasting uncertainties, notably due to the size and volatility of investment income and exports of financial services. Moreover, as in other financial centers, it should be noted that the high level of NFA reached in 2008 increases the estimated equilibrium current account under the ES approach, implying a small depreciation to bring the actual current account into line with its norm.

\begin{tabular}{lc}
\multicolumn{2}{c}{ CGER Assessment of Competitiveness } \\
\hline & \\
& \\
\hline & Estimate \\
\hline Average competitiveness gap (in percent) & 5.51 \\
Macroeconomic balance approach & 5.78 \\
Equilibrium real exchange rate approach & 8.70 \\
External stability approach & 2.05 \\
Memorandum items: & \\
Assessment of competitiveness gap & 8.67 \\
Current account norm (percent of GDP) & 7.00 \\
Projected current account (percent of GDP) & \\
\hline
\end{tabular}




\section{Box 2. Resolution of Troubled Banks}

The resolution of the troubled institutions - three Icelandic banks, Fortis, and Dexia — is proceeding as planned. Specifically:

- $\quad$ The restructuring plan of Glitnir Bank Luxembourg was ratified in court in April 2009, and all depositors have been reimbursed.

- $\quad$ The restructuring of Kaupthing Bank Luxembourg was ratified in July 2009. The company was split into two entities: a bank that started its activities in July 2009 as Banque Havilland and a special purpose vehicle (SPV) that is planned to be unwound over time. Interbank deposits were transferred to the SPV and will be redeemed as assets are sold or mature. All other depositors were either reimbursed or transferred to Banque Havilland.

- $\quad$ The liquidation of Landsbanki Luxembourg was ordered in December 2008, and the unwinding is ongoing. All insured deposits have been paid.

- $\quad$ The banking and insurance businesses of Fortis were split up. BNP Paribas acquired majority stakes in the former, including its Luxembourg subsidiary BGL.

- Dexia is currently reorganizing and deleveraging, including through the controlled scaling down of portfolios and operations. The authorities are closely following these restructuring processes in cooperation with other relevant supervisors.

In addition, close monitoring continues for a few banks with idiosyncratic difficulties, including locally-incorporated subsidiaries of German Landesbanken, which jointly represent about 12 percent of system assets.

increase in the deposit guarantee - in line with an EU-wide initiative - combined with the ECB's monetary policy easing and emergency liquidity provision safeguarded banking sector confidence. ${ }^{3}$ Automatic fiscal stabilizers were allowed to operate fully and welfare and worksupport programs boosted expenditures, resulting in a fiscal balance deterioration of $3 \frac{1}{4}$ percent of GDP in 2009. Luxembourg's fiscal surplus, enviably low public debt, and significant financial assets - almost 10 percent of GDP held by the central governmentprovided the short-term fiscal space needed to accommodate the expansion.

15. Financial conditions have stabilized in 2009. No further bank rescues have been required. Liquidity shortages have vanished and upstream liquidity provision to European parent banks from Luxembourg's financial center has remained a structural feature of the system. Net inflows to the investment fund industry have resumed in the second quarter

\footnotetext{
${ }^{3}$ Financial support of 18.5 percent of GDP was approved, including recapitalization of about $6 \frac{1}{2}$ percent of GDP; the latter was among the highest in the EU as a share of GDP.
} 
of 2009 and remained strong with the assets rebounding to about 90 percent of their October2007 peak. With improving conditions in financial markets, mark-to-market losses in banks' proprietary investment portfolios have been partially reversed. Emergency liquidity provision has been winding down in an orderly manner, and public guarantees in support of weak banks are expected to expire, as planned, in late 2010.

\section{Luxembourg's economy, nevertheless, endured its worst performance in}

30 years. Reflecting its reliance on external markets - exports of goods and services represent about 150 percent of GDP - the economy contracted for five consecutive quarters ending in the second quarter of 2009. Private investment plummeted. Private consumption weakened as large employment losses were experienced in manufacturing and construction despite employment subsidies (partial-work programs). Unemployment rose by $1 \frac{1}{2}$ percentage points to 6 percent. While growth resumed in the second half of the year, output fell by $3 \frac{1}{2}$ percent in 2009 . Inflation declined sharply and, helped also by falling world energy prices, briefly turned negative in mid-2009. Underlying inflation remained on a downward trend.

17. Domestic credit markets have shown only mild signs of a credit crunch. The bulk of bank's balance sheet retrenchment has taken place against financial counterparts, with comparatively little spillover to domestic credit markets. Bank lending spreads have fallen below 200 basis points and compare favorably to their pre-crisis level. Credit quality in domestic retail portfolios remains high with loan impairments below 1 percent despite a recent uptick. The relative resilience of the domestic market reflects a number of factors, notably low household

\begin{tabular}{lccc}
\multicolumn{3}{c}{ Selected Exposures of the Banking System, 2009} \\
\hline & $\begin{array}{c}\text { Share of } \\
\text { Total Bank } \\
\text { Assets }\end{array}$ & $\begin{array}{c}\text { Percentage } \\
\text { of GDP }\end{array}$ & $\begin{array}{c}\text { Percent } \\
\text { Change }(\mathrm{y} / \mathrm{y})\end{array}$ \\
\cline { 2 - 4 } & 47.0 & 1006.2 & -20.6 \\
Interbank Exposure & 23.6 & 503.8 & -8.3 \\
Loans to the Non Banking Sector & 7.9 & 169.1 & -2.8 \\
Luxembourg & 1.8 & 39.0 & -11.8 \\
$\quad$ of which: Corporates & 2.4 & 51.3 & 8.1 \\
Eurozone Households & 9.7 & 207.0 & -8.6 \\
Rest of the World & 6.0 & 127.7 & -14.4 \\
\hline
\end{tabular}

Source: BCL; and IMF staff estimates indebtedness and a moderate drop in house prices compared to other countries.

\section{OUTLOOK}

18. A nascent externally-driven recovery is underway. Luxembourg experienced mild positive growth in the second half of 2009, with the financial and manufacturing sectors leading the way. Business and consumer confidence indicators have also strengthened but, despite recovering housing prices, mixed signals from the construction sector continue. The labor market remains weak but has shown signs of an incipient stabilization and the number of applications for, and use of, short-term work schemes has declined. 
19. Growth will remain below its pre-crisis pace in 2010-11. With the impact of the global financial turmoil slowly receding, and economic conditions gradually improving in Europe, banking sector activity and merchandise exports are projected to continue along mild upward trends. The central scenario envisages 2010-11 growth to average about 3 percent, with a turnaround in the inventory cycle and carry-over growth (about $12 / 3$ percent) providing a boost in 2010 . In addition, the 2010 budget envisages continued stimulus. Still, investment is not expected to experience a sustained expansion following a turnaround in the inventory cycle and private consumption will remain subdued in line with continued labor market sluggishness. The gradual

\begin{tabular}{lrrr}
\multicolumn{4}{c}{ Luxembourg: GDP Growth, 2009-11 } \\
In percent \\
& 2009 & 2010 & 2011 \\
\hline & & (projections) \\
& -3.4 & 3.0 & 2.8 \\
Gross domestic product & -5.1 & 5.1 & 3.2 \\
Total domestic demand & -0.5 & 4.5 & 2.6 \\
Private consumption & -3.3 & -1.5 & 4.5 \\
Gross fixed investment & -1.3 & 0.4 & 0.0 \\
Inventory accumulation 1/ & 0.8 & -0.5 & 0.4 \\
Foreign balance 1/ & -7.6 & 3.6 & 4.5 \\
Exports of goods and nonfactor services & -9.2 & 4.5 & 5.0 \\
Imports of goods and nonfactor services & & & \\
Memo items: & -0.7 & -3.7 & -4.8 \\
General government balance & 5.6 & 5.5 & 5.7 \\
Current account balance & & & \\
\hline 1/ Contribution to GDP Growth & & & \\
Source: Statec; and IMF staff estimates. & & & \\
&
\end{tabular}
strengthening of growth in 2011 is predicated on continued improvement in European trading partners and a mild recovery of private consumption and investment. While inflation is envisaged to remain subdued it has gradually picked up since February bringing forward the next automatic wage adjustment to the summer of 2010.

\section{Risks to the outlook continue to stem primarily from lingering uncertainty in} global financial markets and are skewed to the downside. Luxembourg's financial system has been recovering; systemic risks have abated, and bank deleveraging remains orderly and gradual. In addition, a number of institutions have been unwinding non-core activities, refocusing their business models and improving efficiency. Still, the structure and risks associated to the business model of Luxembourg's financial center have not changed substantially. Locally-incorporated subsidiaries maintain large and concentrated interbank exposures - mainly with their parent groups abroad - and remain exposed to the underlying risks of the latter. Assessing these risks challenges local supervisors.

\section{Capital buffers are high but the adequacy of capital differs across institutions.}

Overall solvency ratios appear to be adequate to withstand tail credit losses stemming from retail and credit portfolios without threatening financial stability. ${ }^{4}$ Still, stress tests conducted by CSSF show a wide dispersion of capital adequacy across banks even though these tests do not reflect credit and liquidity risks originating from intra-group exposures. In addition, despite substantial deleveraging - exceeding 250 percent of GDP in 2009-leverage ratios remain high and disperse. The authorities have requested capital add-ons for a few

\footnotetext{
${ }^{4}$ Overall, solvency ratios are high at about 17.5 percent and have experienced across-the-board improvement due to shrinking balance sheets and fresh capital injections. The distribution of capital has also improved, with only six banks operating with Basel ratios below 10 percent. As in other countries, however, equity capital to assets ratios are low and disperse, with several banks (including some systemically-important institutions) posting ratios below 3 percent. Average risk-weights on assets stand at about 20 to 30 percent.
} 
institutions that were found to be vulnerable to credit risk of their household and corporate portfolios. Moreover, a group of banks appears to be excessively exposed to corporate risk originating from cross-border lending in neighboring countries. Local subsidiaries are also exposed to interest rate risk from maturity and duration mismatches but this risk is less important in relative terms.

\section{Market distress originating from sovereign risk in Europe could pose risks to} Luxembourg's financial sector. Spillover effects could rekindle turbulence in global financial markets and in Luxembourg's financial system. In the event that several sovereigns face difficulties simultaneously, these effects would be particularly challenging and would entail recapitalizing a number of banks. ${ }^{5}$ In addition, the locally-incorporated subsidiaries are vulnerable as these are exposed to indirect risks stemming from their parent bank's exposure to sovereign and corporate credit risk. Exposures to sovereign risk in the portfolios of investment funds are also significant and could entail legal and reputational risks to their sponsoring banks.

\section{The authorities shared the view that the short term outlook had improved but} underscored that downside risks remain. They noted that projections for 2010 are subject to large uncertainties, in particular due to the bearing of financial sector conditions on macroeconomic outcomes, the role of inventories and carry over growth, and the volatility and frequent revisions of national accounts. With respect to the financial system, the authorities stressed that the combination of improved liquidity and high capital ratios - in particular tier one - provide some comfort regarding banking system's capacity to withstand shocks. Cognizant of the risks associated with large sovereign exposures, they noted, however, that these risks are not Luxembourg specific and have remained contained, and supervision has stepped up surveillance and guidance to individual banks regarding sovereign exposures.

\section{Policy Challenges}

\section{A. The Financial System}

\section{The financial system has served Luxembourg's economy well, but the global} financial crisis has highlighted the associated risks and policy challenges. The sheer size of the financial system vis-à-vis the economy entails potentially large contingent fiscal liabilities and exacerbates the "too big to fail" problem. Moreover, Luxembourg's flexible and business-oriented regulatory environment— perceived as a key element of the financial

\footnotetext{
${ }^{5}$ Aggregated risk exposures of Luxembourg banks to sovereign risk from Greece, Ireland, Italy, Portugal, and Spain (GIIPS) represent about 3 percent of system assets and half of banks' regulatory capital. These portfolios comprise public bond holdings (roughly $2 / 3$ of the exposure to sovereigns) and direct credit to sub-national governments primarily to Italy and Spain. The CSSF reports that Luxembourg-based banks do not have material exposures to sovereign risk from GIIPS through derivatives.
} 
center's attractiveness - has allowed banks to centrally manage risks resulting in potentially large liquidity and maturity mismatches in local bank's balance sheets.

\section{A number of risk-mitigating factors are at play, but revisions in key aspects of}

the prudential framework are needed. The EU incorporation and business orientation of the majority of parent banks and a history of close collaboration between Luxembourg's supervisors and those of home countries provide some reassurance. Still, the crisis uncovered weaknesses in the prudential and supervisory frameworks governing liquidity risk and intragroup exposures, as well as in bank's risk management practices. Recent improvements in CSSF's on-site and off-site supervision have stemmed from a more hands on approach and hiring additional expert staff. In addition, the authorities have been developing quantitative tools to monitor and assess liquidity and credit risks, including stress tests. Nonetheless, there is a need to tighten three aspects of the prudential regulatory environment:

- $\quad$ Risks originating from the sizable interbank exposures must be tackled. Of particular attention are liquidity risks generated by the large intra-group transactions of locallyincorporated subsidiaries. Tackling these risks in the context of the supervisory process, as planned, is welcomed, but a case can be made for enhancing the required capital and liquidity buffers associated with these positions. In addition, other prudential responses to mitigate risks associated with intra-group exposures should be considered and weighed against possible adverse effects on the financial center.

- $\quad$ Capital buffers should be better aligned with tail risks in the context of ongoing international initiatives. Despite high capital adequacy ratios in the banking system, leverage ratios are high and disperse, prompting questions regarding the suitability of the structure of risk weights and their level. In addition, the substantial variation in internal rating-based (IRB) estimates across banks, and their limited sensitivity to the current downturn, suggests that banks may be underestimating risks and calls for closer analysis in coordination with home

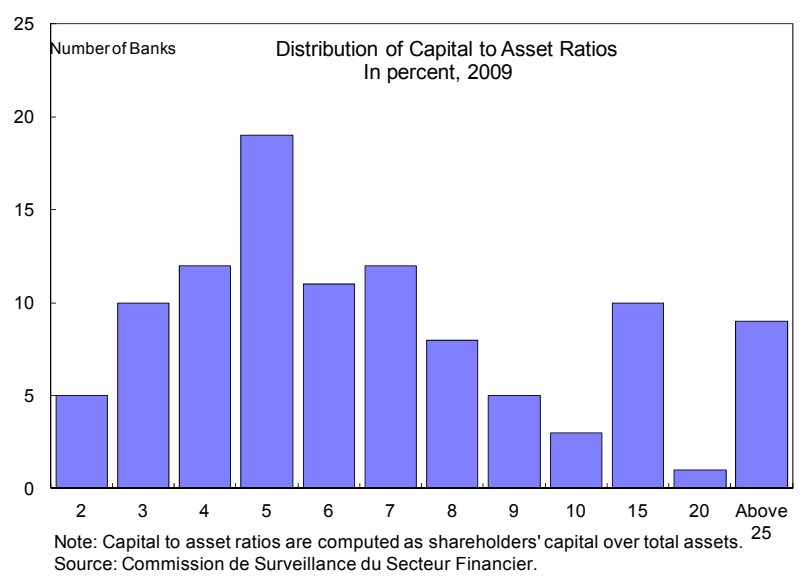
supervisors. The CSSF's focus on banks active in the domestic retail market and the introduction of capital add-ons based on the assessment of bank risk profiles have been appropriate. Forthcoming recommendations from CEBS and the Basel Committee on the level and quality of capital buffers, and possible restrictions on leverage, should be transposed into local regulations promptly as planned. 
- Regulations on quantitative aspects of liquidity risk should move forward. Recentlyenacted regulations on qualitative aspects of liquidity risk address key aspects of bank liquidity management. New regulations establish a mandatory regime of liquidity buffers and banks are now required to treat intra-group exposures explicitly in their liquidity risk management. These regulations assign a proactive role to local management and board regarding liquidity risk and establish a set of principles for collateral management. Still, available prudential indicators are backward looking and fail to capture key aspects of liquidity risk, notably those stemming from off-balance sheet accounts and intra-group positions. In this regard, a new set of indicators should be developed to facilitate the assessment of liquidity risks in individual banks as well as system-wide, exploiting forward-looking information from the contingent liquidity plans of banks and their responses to distressed scenarios. In addition, there is a need to further step up on-site inspections to assess bank's liquidity management and prepare comprehensive liquidity assessments.

\section{Improvements in the supervisory process should go hand in hand with increased} reliance on joint work and information exchange with home supervisors. Locallyincorporated banks are heavily exposed to the parent institution's underlying risks and key risk management is centralized at the banking group level. The assessment of the quality of bank's risk management systems must be conducted at the group level, which will require a fluid exchange of information and collaboration between home and host supervisors. In this context, the authorities are encouraged to continue strengthening collaboration with fellow supervisors and ensuring that supervisory colleges provide a sound platform for risk assessment of large financial groups. The long-standing relationships between the CSSF and peer supervisors proved extremely useful during the crisis and must be further reinforced.

\section{Institutional aspects of the supervisory process also need reinforcement.}

- $\quad$ Enhancing the collaboration between the BCL and the CSSF in monitoring and assessing liquidity risks. The BCL has created two units entrusted with assessing macro-financial stability and monitoring systemic liquidity risk. The latter complements the micro-prudential work carried out by the CSSF and its effectiveness will depend on adequate information exchange and close inter-institutional coordination. In this regard, formalizing the ongoing cooperation and exchange of information between the BCL and the CSSF would be advisable.

- $\quad$ Revamping the deposit guarantee in line with international best practices. The funds set aside by banks through provisions for the deposit guarantee scheme (AGDL) proved essential in honoring all insured deposits in recent bank failures. The intention to replace the current system with a pre-funded scheme through risk-based contributions with a borrowing capacity and the ability to support early resolutions on a least-cost principle would strengthen the financial safety net. The implementation of 
the new scheme should be in line with forthcoming EU guidelines and mindful to avoid overburdening banks' profitability and their ability to extend credit.

28. The crisis also highlighted the importance of establishing formal mechanisms for cross-border bank resolution and burden-sharing. Given the size of the financial sector and the prevalence of foreign-owned subsidiaries, the effectiveness of resolution and crisis management efforts in response to a systemic event hinges on an active coordination with home-country authorities. The harmonization of the crisis resolution frameworks across the EU, the formalization of agreements on burden sharing, and the development of consistent mechanisms for crisis management cross-border bank resolution across the EU are of paramount importance for Luxembourg. These matters extend beyond the domain of Luxembourg and the authorities should remain actively engaged in the EU-level discussions.

\section{Regarding Anti-Money Laundering and Combating the Financing of Terrorism} (AML/CFT), a number of weaknesses were identified in the Financial Action Task Force's (FATF's) recently published evaluation. The ROSC will be circulated to the Board in due course and the authorities are urged to fully implement the FATF's recommendations.

30. While the authorities shared the thrust of staff's assessment, they pointed to features of the financial center that lessen risks. Specifically, they considered that risks associated with large positions with parent banks are mitigated by the structural excess liquidity in the system, and noted the ongoing strengthening of liquidity management by the local subsidiaries. Similarly, they stressed that the banking sector's capital buffers are high and an international consensus has not yet emerged on the definition of leverage ratios. The authorities indicated that several ongoing regulatory initiatives in Luxembourg - in particular on capital, liquidity ratios and deposit insurance — would be implemented as soon as new EU directives were issued. Still, they expressed concern, not just for Luxembourg but also for Europe, about a possibly simultaneous implementation of numerous new financial system regulations. They advocated instead for a gradual application at the EU level, mindful of country-specific features of the financial system and of the potential impact on the economy. The authorities noted their commitment to fully implement the FATF's recommendations.

\section{B. Fiscal Exit Strategy and Long-Run Sustainability}

31. Fiscal policy faces a dilemma. Fiscal

tightening could threaten a weak recovery and prolong labor market sluggishness in 2010. However, allowing fiscal deficits to run unchecked would result in deeper fiscal adjustment in coming years as sharp increases in public spending are expected and make fiscal consolidation and pension reform unavoidable.

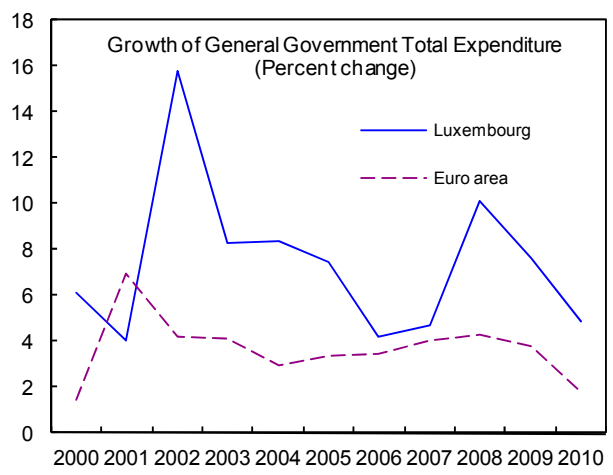




\section{On balance, continued fiscal support is appropriate in the short term.}

Luxembourg's low gross public debt, while rising, still provides near-term fiscal space for continuing counter cyclical policy. Indeed, the 2010 budget entails the fiscal deficit widening to almost 4 percent of GDP. This reflects expenditure increases of $3 / 4$ percent of GDP, equally split between wages and public investment, and a drop in revenues of 2 percent of GDP, reflecting the lagged effects of the crisis on corporate tax collections, which are based on profits from the previous five years. To the extent

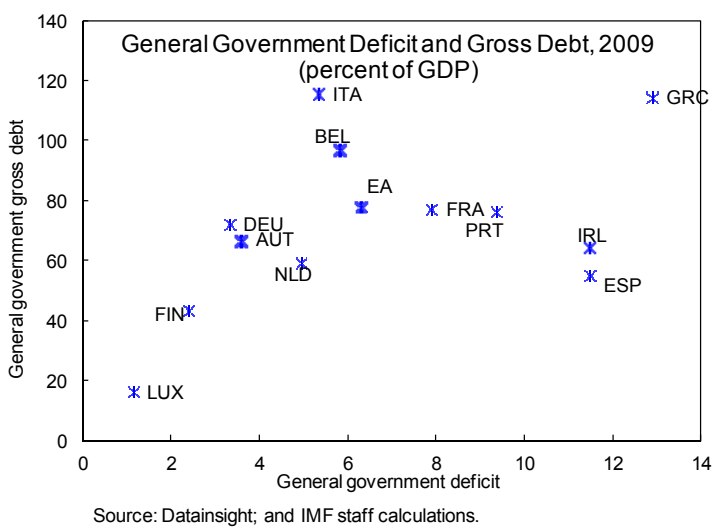
that economic conditions differ from the central scenario, automatic stabilizers should be allowed to operate fully in the upturn.

\section{The 2011 budget should, however, set the} stage for lasting fiscal consolidation. With the delayed impact of the recession continuing to weigh on revenues, the fiscal deficit is poised to widen further in 2011 despite the gradual economic recovery. In the absence of fiscal adjustment, the structural deficit is expected to remain high, exceeding or near the Maastricht limit and leading to a doubling in gross public debt in five years. Moreover, in the medium term tax revenues are expected to gradually decline as the financial sector's role in the economy wanes.

\section{In this regard, there is a pressing need to} articulate an expenditure-based consolidation strategy. The most recent update of the Stability and Growth Program confirms the authorities' goal to balance the budget by 2014 , implying an annual deficit reduction of about 1 percent of GDP. Provided the fiscal consequences of aging are addressed through substantive pension reform, the target provides an apt benchmark to stabilize public debt at about 30 percent of GDP. The recently concluded tripartite discussions on fiscal measures failed to reach agreement between the social partners. The authorities, however, have announced a number of measures focusing on the expenditure side. Besides establishing a cap on
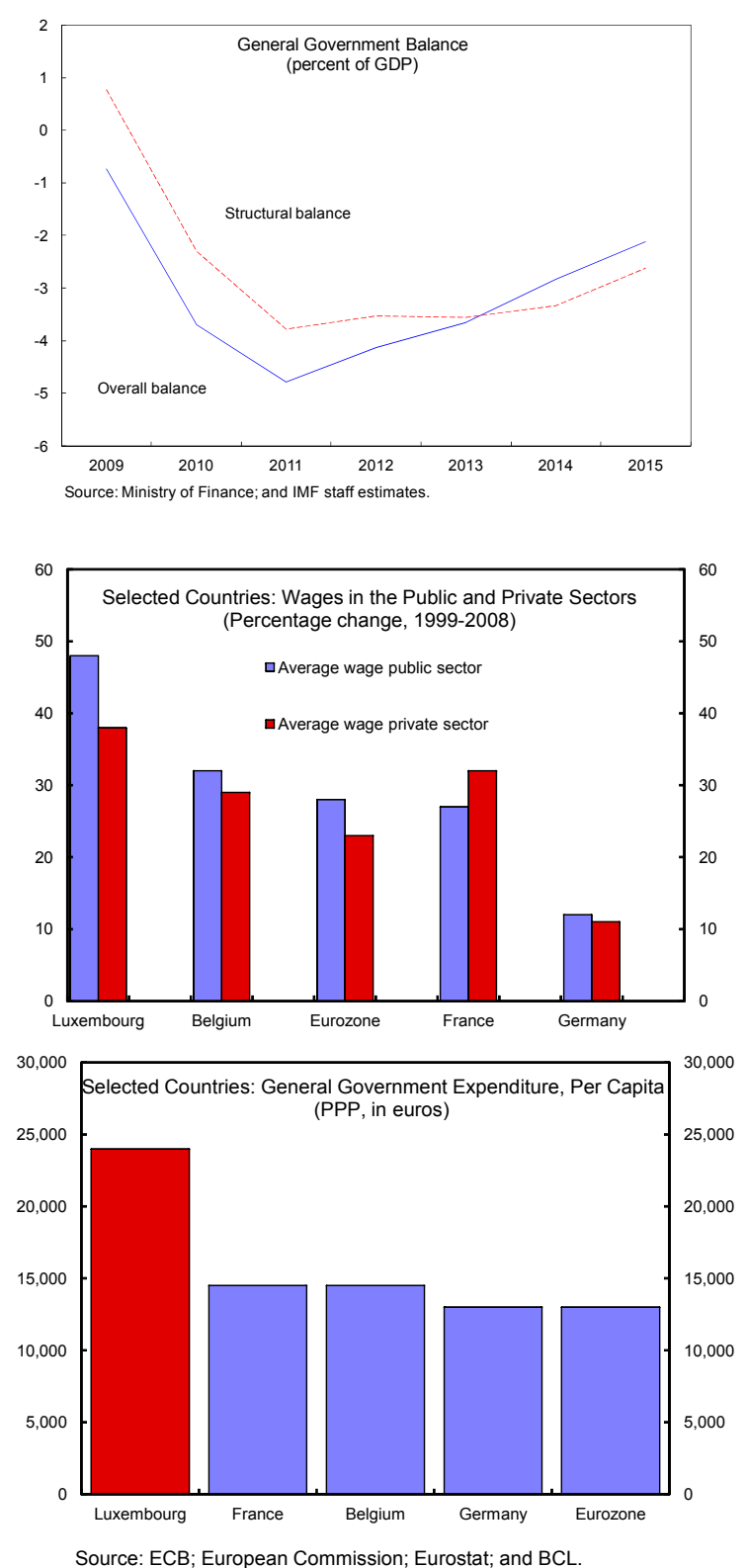
public investment, fiscal consolidation will seek to rationalize current expenditure, social transfers and subsidies, centering on tackling the large deficit at the central government level. Proposed tax measures center on increasing the highest PIT marginal rate, introducing a new top marginal rate for high-income households and a crisis tax on earnings, and boosting the solidarity tax. Still, additional current expenditure adjustment will be needed to balance the budget by 2014 .

\section{Revamping Luxembourg's medium-term fiscal framework would support fiscal} adjustment. The budget process entails an annual exercise with budget documents outlining a threeyear capital-spending program. Introducing forward-looking elements have been considered, notably limiting central government expenditures increases to long-run output growth. But far more would be needed to establish a medium-term fiscal framework that, supported by medium-term targets and revenue projections, would enhance expenditure review and prioritization, facilitate early detection of adjustment needs, and safeguard fiscal sustainability. In line with international best practices, such a framework would be characterized by binding multi-year expenditure ceilings.
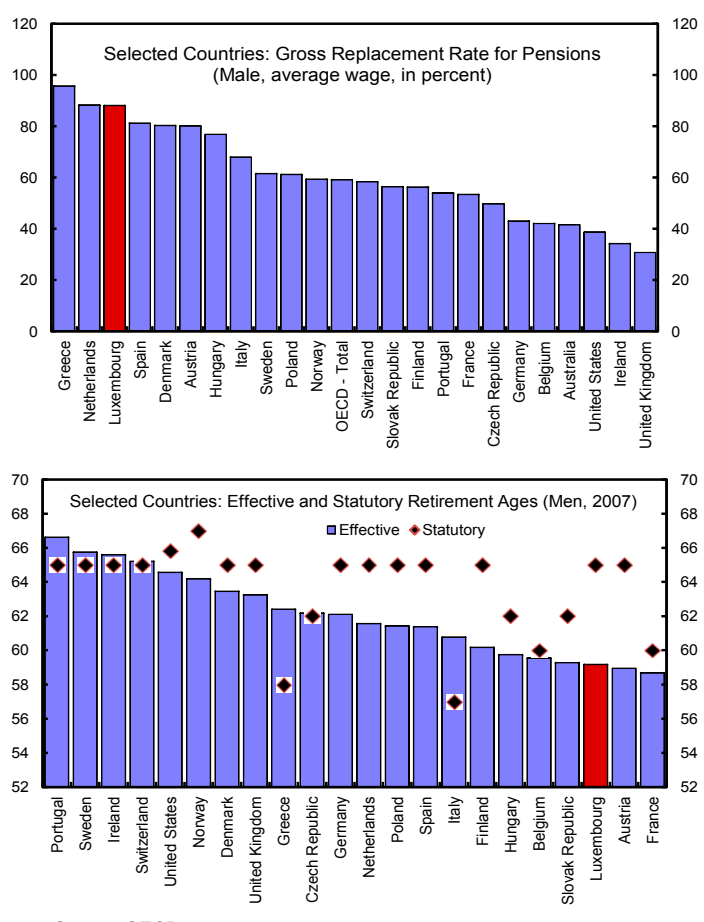

Source: OECD

36. Still, enduring fiscal stability requires substantive pension reform. The pension system generates an annual surplus of about 2 percent of GDP, but surpluses have been shrinking steadily. Gains in life expectancy-10 years in the past 30 years - and generous benefits, including high replacement rates, will continue placing pressure on the pay-as-yougo system. With the highest age-related increases in the EU, official projections for the current system show social security deficits emerging in 15 years and reserves being exhausted in 25 years (Box 3). Against this background, reforms will need to aim for gradually increasing the effective (currently 60 years) and statutory retirement age of 65 including by eliminating design features that encourage early retirement, and improving the alignment of benefits and contributions. In addition, while social partners engaged in quadripartite discussions to devise long-term solutions to contain health care costs, the financial situation of the health care system may require increasing contributions to ensure financial equilibrium in the short term. Putting in place reforms early on will facilitate desirable phasing-in of adjustments and establishing periodic reviews of the social security's financial health can enable timely adjustments in light of economic and demographic developments. Moving ahead promptly can also avoid the need for radical measures as the peak of the fiscal impact of aging nears. 


\section{Box 3. Impact of Age-Related Expenditures on Public Finances}

The adverse impact of aging on public finances is the largest in the EU. The authorities' and EC's calculations project that over the 2060 horizon, age-related spending will increase by about 18 percent of GDP, of which 80 percent corresponds to old-age pensions and 7 percent to health care. The level of health care expenditures would remain slightly below the EU average.
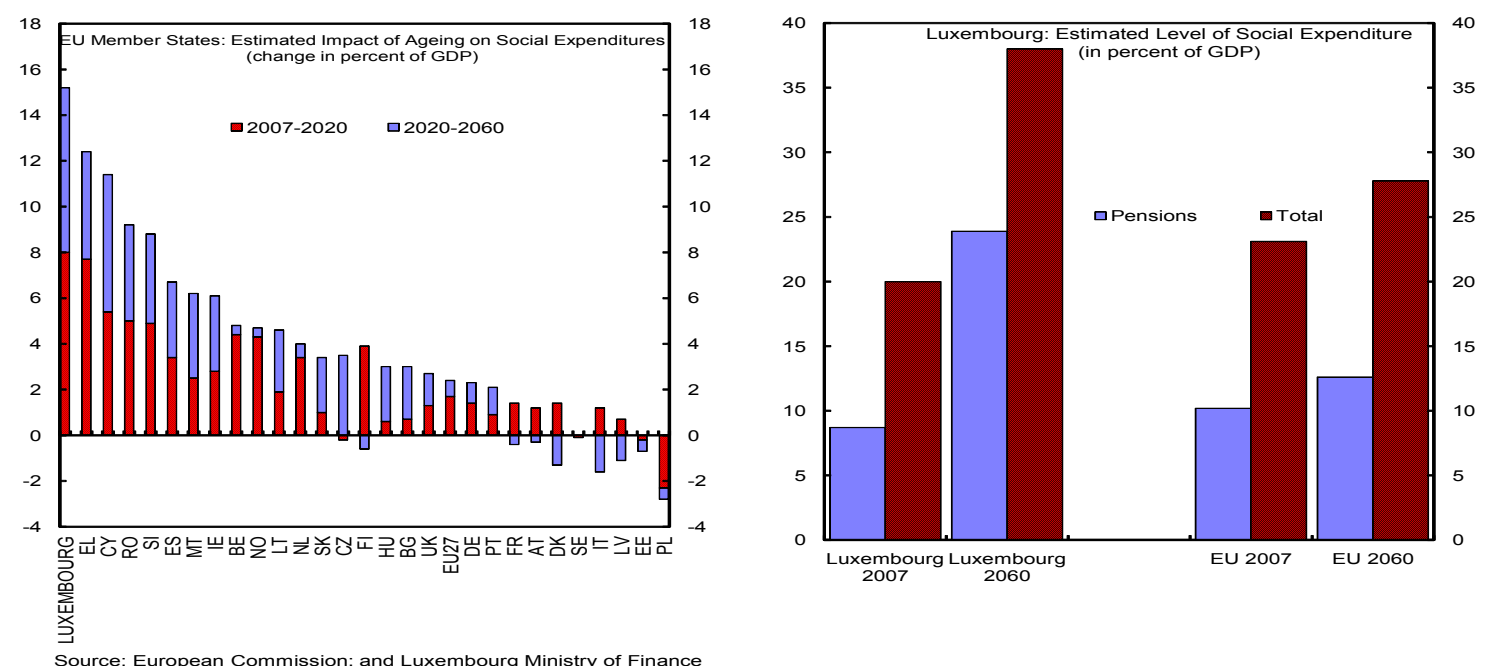

The social security system has accumulated large reserves but these will not suffice to finance the gap. The system has been consistently running surpluses that have resulted in growing reserves, which are projected to reach 28 percent of GDP in 2010 and peak at 46 percent of GDP in 2020. However, the social security budget balance is expected to be in deficit from 2025 onwards and, other things being equal, the reserves will be depleted around 2035.
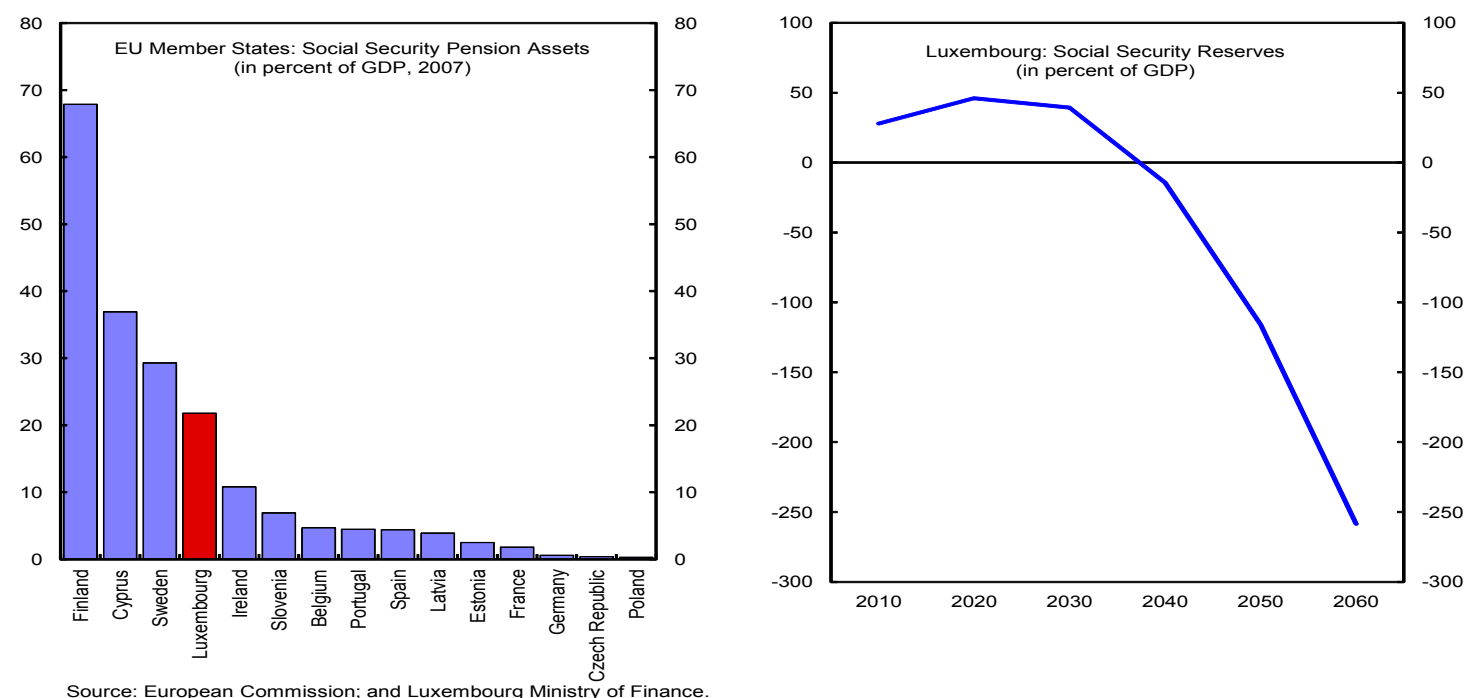

The crisis, moreover, has made the problem more acute. This reflects primarily a $1 \frac{1}{2}$ percentage point drop in potential growth. The impact of aging also hinges on the health of the financial sector and the continued development of Luxembourg's financial center as past social security surpluses were largely due to a young and rapidly expanding population of cross-border financial sector workers. Indeed, 41 percent of pensioners are now non residents and represent 21 percent of pension outlays. A sudden decline in the number of cross border workers would significantly raise the dependency ratio.

Sharp increases in age-related spending reflect the generosity of the system. Compounded by the increasing life expectancy of its beneficiaries, Luxembourg's pension system is characterized by a high replacement ratiothe $4^{\text {th }}$ highest in the OECD, after Greece, Iceland and the Netherlands - and low levels of labor force participation, particularly between the ages of 55 and 64 years. 


\section{The authorities concurred with the need to consolidate fiscal accounts and} preserve fiscal sustainability in the face aging-related expenditure pressures. They noted that the fiscal stimulus had been beneficial - in particular to mitigate the effects of the crisis on employment. The authorities were mindful of restoring the financial health of fiscal accounts that had been achieved by prudent fiscal management. They stressed that their policies created the fiscal space that enabled them to counteract the effects of downturn, particularly its impact on household income. Still, given the openness of Luxembourg's economy, the authorities expressed reservations regarding fiscal policy's counter-cyclical role. They underscored the importance of containing the tax burden in the medium term and restoring debt sustainability, including by running fiscal surpluses. The authorities also noted that the adoption of a medium-term fiscal framework may help in securing a continued adjustment. Regarding the adjustment, they expressed their firm commitment to consolidate fiscal accounts and take action on aging related reforms by end-2010.

\section{Fostering Long-Run Growth}

\section{Luxembourg's financial-sector led growth faces headwinds from global} deleveraging and an international push to harmonize taxation and enhance bank transparency. Even before the crisis, international calls to eliminate or severely limit tax advantages and ease bank privacy legislation had not augured well for Luxembourg's aboveaverage economic growth. Parts of retail and private banking had already started to adjust. In the wake of the global financial crisis, financial institutions worldwide have continued deleveraging further eroding Luxembourg's growth prospects. Available estimates suggest that a 1percent decline in financial sector value added slows economic growth by about $1 / 2$ percentage points in a year's time, with smaller losses in two subsequent years. But, in line with the international experience, the financial crisis will likely entail a lasting impact on output reflecting a shift toward a less

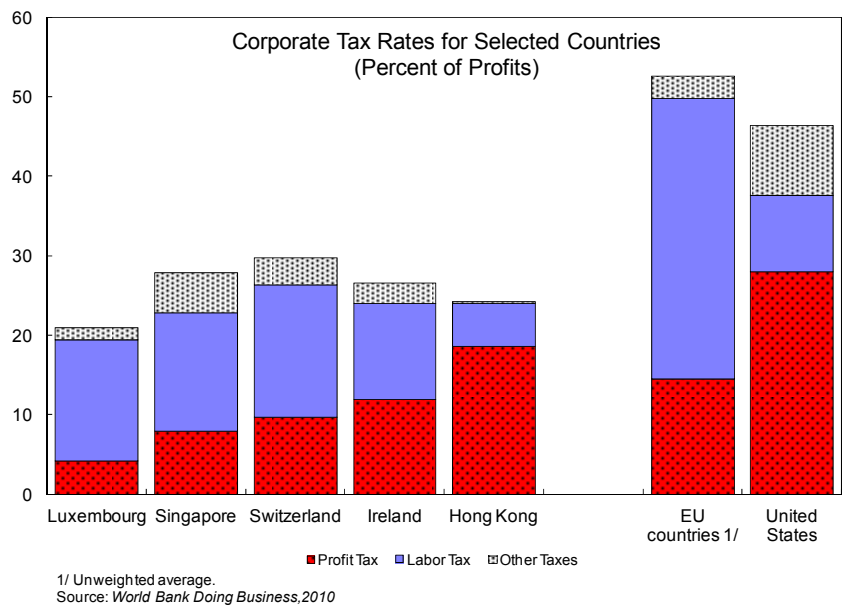
exuberant financial activity, a lower expansion of the cross border labor force and declines in productivity. While Luxembourg may be able to keep and attract back office and related services - increasing under pressure from lower cost countries - the economy's growth potential has declined: official estimates lowered long-run growth by between $1 \frac{1}{2}$ and 2 percentage points to $2 \frac{1}{2}$ percent. Although difficult to estimate, the estimated impact appears commensurate with the size of Luxembourg's financial sector and available crosscounty evidence. 
Estimates of the Impact of Financial Crises on Economic Output

\begin{tabular}{|c|c|c|}
\hline & Impact on output & Studies \\
\hline \multirow[t]{5}{*}{ Luxembourg } & Potential growth slows from 4.5 percent in 2007 to 2.7 percent in & Luxembourg's 11th SGP Update \\
\hline & 2020 and 2 percent afterwards & \\
\hline & $\begin{array}{l}\text { Potential growth declines to } 2.2 \text { percent between } 2012 \text { and 2030, } \\
\text { assuming constant labor force }\end{array}$ & BCL (2010) \\
\hline & Potential growth lower by 1 percent by 2011 & Statec (2009) \\
\hline & $\begin{array}{l}\text { Decline by } 1 \text { percent in financial sector value added leads to GDP } \\
\text { decline of } 0.6 \text { percent in the first year and } 0.3 \text { percent the following } \\
\text { two years }\end{array}$ & Statec (2009) \\
\hline \multicolumn{3}{|l|}{ Economies with large financial sectors } \\
\hline Belgium & $\begin{array}{l}\text { Potential growth slows from } 1.9 \text { percent in } 2007 \text { to between } 0.7 \text { and } \\
0.8 \text { percent before gradually returning to potential growth pre crisis } \\
\text { trend of } 1.5 \text { percent }\end{array}$ & IMF 2009 Article IV Consultation \\
\hline UK & $\begin{array}{l}\text { Potential growth lowered by } 1-1.5 \text { percent to } 0.25-1.25 \text { percent in } \\
2010 \text { and to } 1.75-2.25 \text { percent in the medium term }\end{array}$ & IMF 2009 Article IV Consultation \\
\hline Switzerland & $\begin{array}{l}\text { Potential growth lowered by } 1.25 \text { in } 2009 \text { and by } 1 / 2 \text { percent over } \\
\text { the medium term }\end{array}$ & IMF 2010 Article IV Consultation \\
\hline \multicolumn{3}{|l|}{ Cross country studies } \\
\hline Eurozone + Denmark, Sweden, UK & $\begin{array}{l}\text { Potential growth in } 2009 \text { and } 2010 \text { lowered to } 0.7-0.8 \text { percent from } \\
1.3-1.6 \text { percent }\end{array}$ & European Commission (2009) \\
\hline OECD & $\begin{array}{l}\text { Potential output lower by } 1.5 \text { to } 2.4 \text { percent on average, } 4 \text { percent for } \\
\text { severe crises }\end{array}$ & Furceri and Mourougane (OECD,2009) \\
\hline Advanced and Emerging economies & Output loss is 10 percent on average 7 years after a banking crisis & IMF WEO (October 2009) \\
\hline
\end{tabular}

\section{Luxembourg's resilience as an economic and financial center will depend on} cultivating its comparative advantage in niche activities. Years of experience have resulted in considerable expertise in accounting, legal, and back office services that can support new niche activities and underpin future growth. To safeguard these advantages and foster a flexible economy, there will be a need to address skill mismatches with a view to curtail high unemployment among residents. This should be complemented by an agreement among social partners to moderate wage increases and eliminate automatic backward-looking wage indexation over time. In this regard, the authorities' proposal to adjust the price index is a welcome step to limit its adverse effects on competiveness. ${ }^{6}$

\section{The authorities agreed that the global financial crisis may represent a paradigm} shift for the Luxembourg financial center but it also provides opportunities to continue building on its success. The authorities considered fostering the economy's competitiveness as a top priority and shaped a substantial part of the government program around continuously monitoring the situation on the ground and proposing innovative solutions as needed. They noted that flexibility was needed to continue building and taking advantage of high-value added opportunities, particularly when a number of regulatory changes are in train. Although views differ on the extent of the deterioration in competitiveness and the solutions to remedy it, social partners agreed that the comparative advantage of

\footnotetext{
${ }^{6}$ Together with Belgium and Spain, Luxembourg is one of the three European countries with a dominant system of backward looking and automatic indexation mechanism.
} 
Luxembourg's economy lies on high value added activities, supported by a highly educated workforce. Initiatives to develop financial sector niche activities are ongoing. However, some of these activities could have low employment content and thus the authorities noted the need for continued gains in productivity and wage restraint. They expressed, nonetheless, their commitment to automatic wage indexation mechanism for social cohesion, with the proposed adjustments serving to mitigate adverse effects on competitiveness. 
Figure 1. Luxembourg: Confidence Indicators
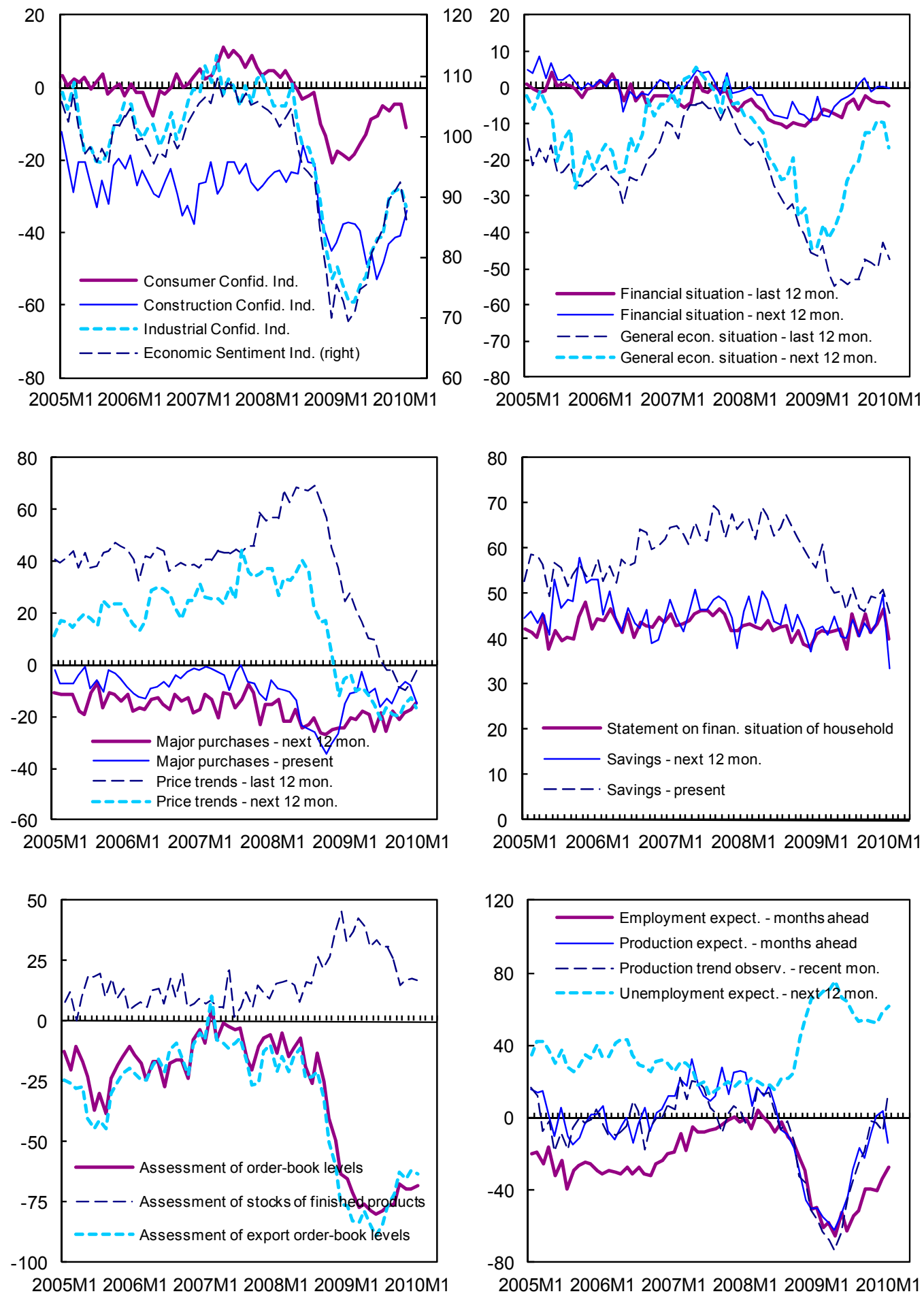

Source: Eurostat. 
Figure 2. Luxembourg: High Frequency Financial Indicators
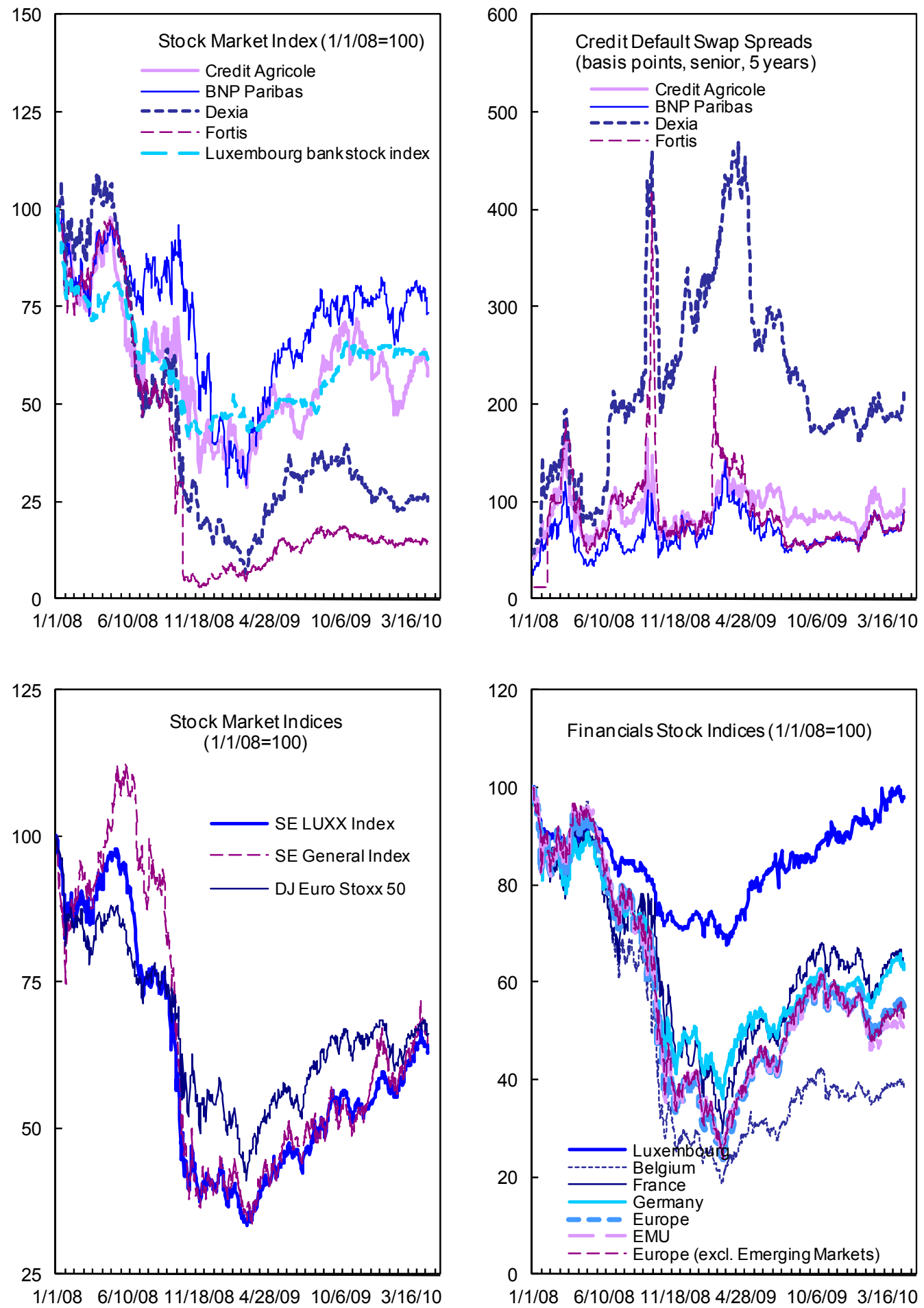

Source: Thomson Financial/Reuters/Datastream. 
Figure 3. Luxembourg: Aggregate Banking Sector Assets and Funding
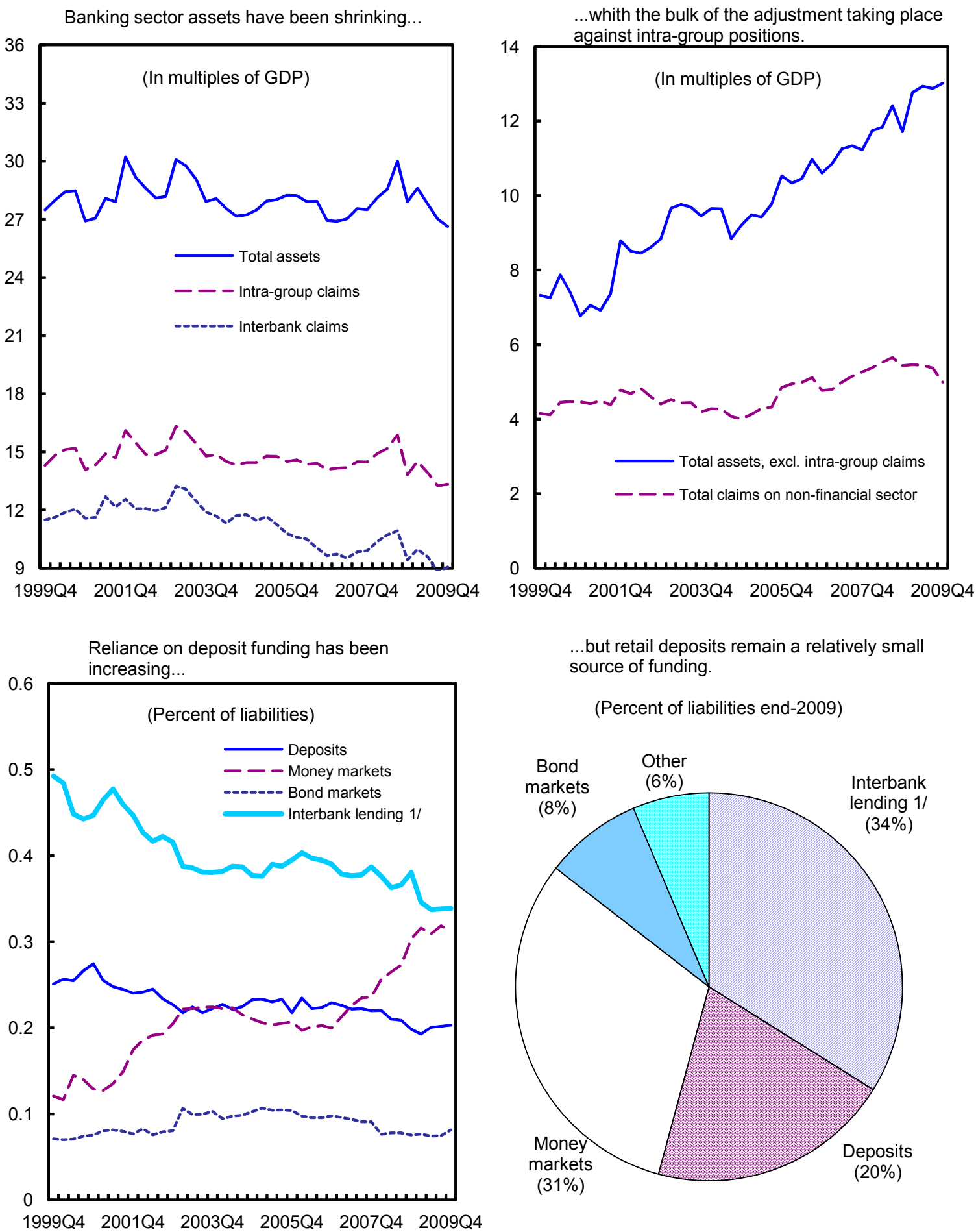

...but retail deposits remain a relatively small
source of funding.

(Percent of liabilities end-2009)

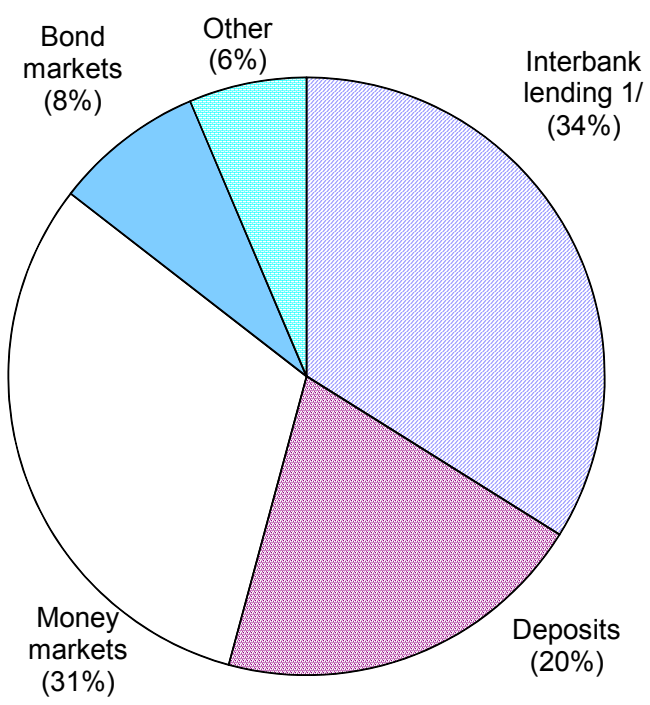

Source: IFS; and IMF staff estimates. 
Table 1. Luxembourg: Basic Data, 2006-11

\begin{tabular}{|c|c|c|c|c|c|c|}
\hline & & & & & Est. & Proj. \\
\hline & 2006 & 2007 & 2008 & 2009 & 2010 & 2011 \\
\hline \multicolumn{7}{|l|}{ Real Economy (change in percent) } \\
\hline Gross domestic product & 5.6 & 6.5 & 0.0 & -3.4 & 3.0 & 2.8 \\
\hline Total domestic demand & 2.1 & 4.3 & 3.2 & -5.1 & 5.1 & 3.2 \\
\hline Private consumption & 2.7 & 2.8 & 3.9 & -0.5 & 4.5 & 2.6 \\
\hline Public consumption & 2.8 & 2.9 & 3.0 & 2.9 & 2.6 & 1.5 \\
\hline Gross investment & 0.8 & 7.6 & 2.3 & -17.1 & 8.7 & 5.4 \\
\hline Foreign balance $1 /$ & 3.6 & 3.1 & -2.4 & 0.8 & -0.5 & 0.4 \\
\hline Exports of goods and nonfactor services & 13.3 & 8.8 & 1.5 & -7.6 & 3.6 & 4.5 \\
\hline Imports of goods and nonfactor services & 12.9 & 8.3 & 3.3 & -9.2 & 4.5 & 5.0 \\
\hline \multicolumn{7}{|c|}{ Employment and unemployment (thousands, unless indicated) } \\
\hline Resident labor force & 212.5 & 217.3 & 223.2 & 226.7 & 230.0 & 233.5 \\
\hline Unemployed & 9.5 & 9.6 & 9.9 & 16.2 & 14.7 & 13.7 \\
\hline (As a percent of total labor force) & 4.5 & 4.4 & 4.4 & 7.1 & 6.4 & 5.8 \\
\hline Resident employment & 203.1 & 207.7 & 213.3 & 210.5 & 215.3 & 219.8 \\
\hline (change in percent) & 2.2 & 2.3 & 2.7 & -1.3 & 2.3 & 2.1 \\
\hline Cross-border workers (net) & 115.9 & 125.5 & 135.4 & 131.3 & 132.7 & 132.9 \\
\hline Total employment & 319.0 & 333.2 & 348.7 & 341.8 & 348.0 & 352.8 \\
\hline (Change in percent) & 3.6 & 4.5 & 4.7 & -2.0 & 1.8 & 1.4 \\
\hline \multicolumn{7}{|l|}{ Prices and costs (change in percent) } \\
\hline CPI (harmonized), p.a. & 2.3 & 2.2 & 2.3 & 2.5 & 2.6 & 2.7 \\
\hline CPI (national definition), p.a. & 2.7 & 2.3 & 3.4 & 0.4 & 2.0 & 1.5 \\
\hline Average nominal wage growth $2 /$ & 3.3 & 3.5 & 2.1 & 1.9 & 0.0 & 2.3 \\
\hline Nominal unit labor costs $2 /$ & -4.8 & -1.2 & 1.9 & 4.1 & -6.5 & 2.3 \\
\hline \multicolumn{7}{|l|}{ Public finances (percent of GDP) $3 /$} \\
\hline General government revenues & 39.7 & 39.8 & 40.1 & 41.6 & 37.7 & 36.8 \\
\hline General government expenditures & 38.3 & 36.2 & 37.2 & 42.4 & 41.4 & 41.6 \\
\hline General government balance & 1.4 & 3.6 & 2.9 & -0.7 & -3.7 & -4.8 \\
\hline General government gross debt & 6.5 & 6.7 & 13.7 & 16.4 & 19.6 & 24.1 \\
\hline \multicolumn{7}{|l|}{ Balance of Payments (percent of GDP) } \\
\hline Current account & 10.3 & 9.7 & 5.3 & 5.6 & 5.5 & 5.7 \\
\hline Balance on goods & -10.0 & -9.4 & -10.9 & -8.0 & -9.0 & -9.3 \\
\hline Balance on services & 48.6 & 53.8 & 51.7 & 47.7 & 42.4 & 40.9 \\
\hline Net factor income & -25.6 & -30.3 & -30.8 & -31.3 & -23.7 & -21.7 \\
\hline Balance on current transfers & -2.7 & -4.3 & -4.7 & -2.7 & -4.2 & -4.2 \\
\hline \multicolumn{7}{|l|}{ Exchange rates $4 /$} \\
\hline U.S. dollar per euro & 1.3 & 1.4 & 1.5 & 1.4 & 1.4 & $\ldots$ \\
\hline percent change & 0.8 & 9.2 & 7.4 & -5.4 & -7.0 & $\ldots$ \\
\hline Nominal effective rate $(2005=100)$ & 100.2 & 101.5 & 103.0 & 103.1 & 102.3 & \\
\hline percent change & 0.2 & 1.3 & 1.5 & 0.1 & -0.7 & $\ldots$ \\
\hline Real effective rate (CPI based; $2005=100)$ & 100.9 & 102.3 & 104.0 & 104.4 & 103.7 & \\
\hline percent change & 0.9 & 1.3 & 1.7 & 0.4 & -0.2 & $\ldots$ \\
\hline \multicolumn{7}{|l|}{ Interest rates 4/ } \\
\hline Government bond yield & 3.9 & 4.6 & 4.2 & 4.2 & 3.7 & $\ldots$ \\
\hline
\end{tabular}

Sources: Data provided by the authorities; IMF, WEO database; and IMF staff calculations.

1/ Contribution to GDP growth.

2/ Overall economy.

3/ Fiscal projections are based on unchanged policies and thus do not reflect fiscal consolidation measures announced on May 5, 2010.

4/ For 2010, data refer to February. 
Table 2. Luxembourg: General Government Operations, 2006-14 1/

\begin{tabular}{|c|c|c|c|c|c|c|c|c|c|}
\hline & \multicolumn{6}{|c|}{ Est. } & \multicolumn{2}{|c|}{ Proj. } & \multirow[b]{2}{*}{2014} \\
\hline & 2006 & 2007 & 2008 & 2009 & 2010 & 2011 & 2012 & 2013 & \\
\hline & \multicolumn{9}{|c|}{ (In percent of GDP) } \\
\hline Revenue & 39.7 & 39.8 & 40.1 & 41.6 & 37.7 & 36.8 & 37.4 & 37.8 & 38.1 \\
\hline Tax revenue & 25.4 & 25.5 & 25.2 & 25.8 & 22.8 & 21.7 & 22.3 & 22.8 & 23.3 \\
\hline Indirect taxes & 12.5 & 12.4 & 11.8 & 11.9 & 11.0 & 10.6 & 10.6 & 10.6 & 10.6 \\
\hline Direct taxes & 12.9 & 13.0 & 13.4 & 13.9 & 11.8 & 11.2 & 11.7 & 12.2 & 12.7 \\
\hline Social security contributions & 10.7 & 10.7 & 10.9 & 12.1 & 11.4 & 11.3 & 11.3 & 11.2 & 11.0 \\
\hline Other revenue & 3.5 & 3.7 & 3.9 & 3.7 & 3.4 & 3.7 & 3.7 & 3.8 & 3.8 \\
\hline Expenditure & 38.3 & 36.2 & 37.2 & 42.4 & 41.4 & 41.6 & 41.5 & 41.4 & 41.0 \\
\hline Current expenditure & 36.0 & 34.6 & 35.5 & 40.5 & 39.2 & 39.3 & 39.2 & 39.0 & 38.5 \\
\hline Wages and salaries & 7.3 & 7.1 & 7.1 & 7.9 & 7.8 & 7.8 & 7.7 & 7.6 & 7.6 \\
\hline Goods and services & 3.0 & 3.0 & 3.2 & 3.6 & 3.6 & 3.5 & 3.5 & 3.5 & 3.5 \\
\hline Social transfers and pensions & 18.1 & 17.3 & 18.1 & 20.7 & 19.7 & 19.7 & 19.5 & 19.5 & 19.3 \\
\hline Social security benefits & 15.8 & 15.1 & 15.8 & 17.8 & 18.2 & 18.4 & 18.7 & 18.9 & 19.2 \\
\hline Interest payments & 0.2 & 0.2 & 0.3 & 0.5 & 0.4 & 0.5 & 0.7 & 0.9 & 1.1 \\
\hline Other current expenditure & 7.3 & 7.0 & 6.8 & 7.8 & 7.7 & 7.8 & 7.6 & 7.5 & 7.0 \\
\hline Net acquisition of nonfinancial assets & 2.3 & 1.6 & 1.7 & 1.9 & 2.2 & 2.3 & 2.3 & 2.4 & 2.5 \\
\hline Overall balance & 1.4 & 3.6 & 2.9 & -0.7 & -3.7 & -4.8 & -4.1 & -3.7 & -2.8 \\
\hline
\end{tabular}

Source: Luxembourg Statistical Office; and Staff Estimates.

1/ Fiscal projections are based on unchanged policies and thus do not reflect fiscal consolidation measures announced on May 5, 2010. 
Table 3. Luxembourg: External Current Account, 2006-14

\begin{tabular}{|c|c|c|c|c|c|c|c|c|c|}
\hline & \multicolumn{6}{|c|}{ Est. } & \multicolumn{3}{|l|}{ Proj. } \\
\hline & 2006 & 2007 & 2008 & 2009 & 2010 & 2011 & 2012 & 2013 & 2014 \\
\hline & \multicolumn{9}{|c|}{ (In percent of GDP) } \\
\hline Current account & 10.3 & 9.7 & 5.3 & 5.6 & 5.5 & 5.7 & 6.1 & 6.6 & 7.0 \\
\hline $\begin{array}{l}\text { Balance on goods and services } \\
\text { Trade balance } \\
\text { Merch exports } \\
\text { Merch imports } \\
\text { Balance on services } \\
\text { Services exports } \\
\text { Services imports }\end{array}$ & $\begin{array}{r}38.6 \\
-10.0 \\
38.5 \\
48.5 \\
48.6 \\
118.2 \\
69.6\end{array}$ & $\begin{array}{r}44.3 \\
-9.4 \\
35.5 \\
44.9 \\
53.8 \\
127.5 \\
73.8\end{array}$ & $\begin{array}{r}40.8 \\
-10.9 \\
37.0 \\
47.9 \\
51.7 \\
123.0 \\
71.3\end{array}$ & $\begin{array}{r}39.7 \\
-8.0 \\
29.5 \\
37.5 \\
47.7 \\
116.1 \\
68.4\end{array}$ & $\begin{array}{r}33.4 \\
-9.0 \\
26.6 \\
35.6 \\
42.4 \\
105.2 \\
62.8\end{array}$ & $\begin{array}{r}31.5 \\
-9.3 \\
26.8 \\
36.1 \\
40.9 \\
104.4 \\
63.6\end{array}$ & $\begin{array}{r}30.1 \\
-9.4 \\
27.0 \\
36.4 \\
39.4 \\
104.4 \\
65.0\end{array}$ & $\begin{array}{r}28.8 \\
-9.5 \\
27.4 \\
36.9 \\
38.4 \\
105.7 \\
67.4\end{array}$ & $\begin{array}{r}27.6 \\
-9.7 \\
27.8 \\
37.4 \\
37.3 \\
107.3 \\
70.0\end{array}$ \\
\hline $\begin{array}{l}\text { Net factor income } \\
\text { Compensation of employees, net } \\
\text { Compensation of employees, credit } \\
\text { Compensation of employees, debit } \\
\text { Investment income, net } \\
\text { Investment income, credit } \\
\text { Investment income, debit }\end{array}$ & $\begin{array}{r}-25.6 \\
-13.9 \\
3.1 \\
17.0 \\
-11.7 \\
296.9 \\
308.7\end{array}$ & $\begin{array}{r}-30.3 \\
-14.4 \\
3.0 \\
17.4 \\
-15.8 \\
324.5 \\
340.3\end{array}$ & $\begin{array}{r}-30.8 \\
-15.6 \\
2.9 \\
18.5 \\
-15.2 \\
345.7 \\
360.9\end{array}$ & $\begin{array}{r}-31.3 \\
-16.6 \\
3.2 \\
19.9 \\
-14.7 \\
263.0 \\
277.7\end{array}$ & $\begin{array}{r}-23.7 \\
-14.3 \\
3.1 \\
17.4 \\
-9.5 \\
243.7 \\
253.2\end{array}$ & $\begin{array}{r}-21.7 \\
-13.6 \\
3.1 \\
16.7 \\
-8.1 \\
234.1 \\
242.2\end{array}$ & $\begin{array}{r}-19.8 \\
-13.0 \\
3.1 \\
16.0 \\
-6.9 \\
224.7 \\
231.6\end{array}$ & $\begin{array}{r}-18.1 \\
-12.3 \\
3.0 \\
15.3 \\
-5.8 \\
214.7 \\
220.5\end{array}$ & $\begin{array}{r}-16.4 \\
-11.6 \\
3.0 \\
14.6 \\
-4.8 \\
204.9 \\
209.7\end{array}$ \\
\hline Balance on current transfers & -2.7 & -4.3 & -4.7 & -2.7 & -4.2 & -4.2 & -4.2 & -4.2 & -4.2 \\
\hline Capital and financial account & -10.3 & -9.7 & -5.2 & -5.4 & -5.4 & -5.6 & -6.0 & -6.5 & -6.9 \\
\hline Capital account & -0.9 & -0.4 & -0.6 & -0.7 & -0.1 & -0.1 & -0.1 & -0.1 & -0.1 \\
\hline $\begin{array}{l}\text { Financial account } \\
\text { Direct investment, net } \\
\text { Portfolio investment } \\
\text { Financial derivatives } \\
\text { Other investments }\end{array}$ & $\begin{array}{r}-9.4 \\
32.7 \\
172.7 \\
22.4 \\
-237.3\end{array}$ & $\begin{array}{r}-9.3 \\
-127.4 \\
261.2 \\
27.3 \\
-170.4\end{array}$ & $\begin{array}{r}-4.6 \\
-60.1 \\
59.5 \\
-36.2 \\
32.2\end{array}$ & $\begin{array}{r}-4.7 \\
-41.4 \\
5.4 \\
-27.5 \\
58.8\end{array}$ & $\begin{array}{r}-5.3 \\
-9.4 \\
-95.4 \\
-1.1 \\
100.6\end{array}$ & $\begin{array}{r}-5.5 \\
-8.6 \\
-104.9 \\
-1.1 \\
109.1\end{array}$ & $\begin{array}{r}-5.9 \\
-8.2 \\
-104.9 \\
-1.1 \\
108.3\end{array}$ & $\begin{array}{r}-6.4 \\
-7.9 \\
-104.9 \\
-1.1 \\
107.4\end{array}$ & $\begin{array}{r}-6.9 \\
-7.5 \\
-104.9 \\
-1.1 \\
106.7\end{array}$ \\
\hline Change in reserve assets of the $B C L$ & 0.1 & 0.2 & -0.2 & -0.2 & -0.1 & -0.1 & -0.1 & -0.1 & -0.1 \\
\hline Errors and omissions & -0.1 & -0.2 & 0.1 & -0.1 & 0.0 & 0.0 & 0.0 & 0.0 & 0.0 \\
\hline Balance of payments & 0.0 & 0.0 & 0.2 & 0.3 & 0.1 & 0.1 & 0.1 & 0.1 & 0.1 \\
\hline
\end{tabular}

Source: Statec; and IMF staff projections. 
Table 4. Luxembourg: Financial Soundness Indicators, 2005-09 (In percent)

\begin{tabular}{|c|c|c|c|c|c|}
\hline & 2005 & 2006 & 2007 & 2008 & $20091 /$ \\
\hline \multicolumn{6}{|l|}{ Capital Adequacy } \\
\hline Regulatory capital to risk-weighted assets & 15.5 & 15.3 & 14.3 & 15.4 & 18.9 \\
\hline Regulatory Tier 1 capital to risk-weighted assets & 12.9 & 12.7 & 12.2 & 13.0 & 16.5 \\
\hline Capital to assets & 4.1 & 4.1 & 4.1 & 4.8 & 6.0 \\
\hline \multicolumn{6}{|l|}{ Profitability And Efficiency } \\
\hline Return on assets & 0.7 & 0.9 & 0.8 & 0.2 & 0.6 \\
\hline Return on equity & 17.0 & 22.1 & 20.4 & 5.5 & 11.6 \\
\hline Interest margin to gross income & 25.1 & 26.2 & 27.0 & 37.7 & 36.5 \\
\hline Trading income to total income & 5.6 & 4.9 & 1.9 & -8.9 & 5.6 \\
\hline Noninterest expenses to gross income & 53.0 & 48.4 & 50.5 & 56.2 & 56.3 \\
\hline Personnel expenses to noninterest expenses & 38.5 & 38.7 & 37.9 & 35.7 & 38.7 \\
\hline \multicolumn{6}{|l|}{ Asset Quality And Structure } \\
\hline Nonperforming loans net of provisions to capital & 1.4 & 1.0 & 1.6 & $\ldots$ & 10.9 \\
\hline Nonperforming loans to total gross loans & 0.2 & 0.1 & 0.2 & $\ldots$ & 1.3 \\
\hline Residential real estate loans to total loans & 1.8 & 2.0 & 2.1 & 2.2 & 2.8 \\
\hline \multicolumn{6}{|l|}{ Sectoral distribution of loans (in \% of total loans) } \\
\hline Residents & 19.7 & 18.4 & 22.5 & 26.6 & 23.4 \\
\hline Deposit Takers & 12.4 & 10.2 & 11.7 & 10.7 & 9.8 \\
\hline Central Bank & 1.0 & 1.6 & 1.5 & 6.4 & 2.3 \\
\hline Other Financial Corporations & 2.6 & 2.5 & 4.7 & 4.2 & 4.8 \\
\hline General Government & 0.2 & 0.2 & 0.3 & 0.4 & 0.4 \\
\hline Nonfinancial Corporations & 1.3 & 1.5 & 1.8 & 2.4 & 2.6 \\
\hline Other Domestic Sectors & 2.2 & 2.4 & 2.5 & 2.6 & 3.4 \\
\hline Non Residents & 80.3 & 81.6 & 77.5 & 73.4 & 76.6 \\
\hline \multicolumn{6}{|l|}{ Liquidity } \\
\hline Liquid assets to total assets & 53.3 & 54.5 & 53.2 & 59.0 & 55.9 \\
\hline Liquid assets to short-term liabilities & 64.3 & 66.0 & 64.1 & 67.8 & 64.7 \\
\hline Customer deposits to total (non interbank) loans & 174.3 & 182.2 & 160.7 & 134.7 & 137.5 \\
\hline \multicolumn{6}{|l|}{ Foreign Exchange } \\
\hline Foreign currrency denominated loans to total loans & 41.4 & 42.3 & 34.5 & 30.2 & 28.1 \\
\hline $\begin{array}{l}\text { Foreign currency denominated liabilities to total } \\
\text { liabilities }\end{array}$ & 37.5 & 37.5 & 33.8 & 29.1 & 28.8 \\
\hline Net open foreign exchange to capital & -7.8 & -14.0 & 3.1 & 1.6 & -0.6 \\
\hline \multicolumn{6}{|l|}{ Other Indicators } \\
\hline Household debt to GDP & 41.8 & 40.5 & 45.3 & 48.3 & 52.2 \\
\hline $\begin{array}{l}\text { Spread between reference lending and deposit rates } \\
\text { (in basis points) }\end{array}$ & 172 & 187 & 225 & 220 & 166 \\
\hline
\end{tabular}

Source: Central Bank of Luxembourg.

1/ There is a break in the series in 2009 due to the adoption of IAS and IFRS in 2008. 


\section{INTERNATIONAL MONETARY FUND}

\section{LUXEMBOURG}

Staff Report for the 2010 Article IV Consultation-Informational Annex

Prepared by European Department

May 12,2010

Contents

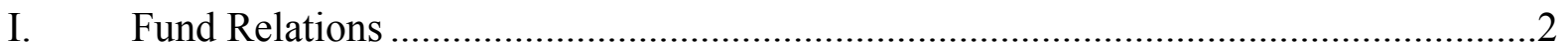

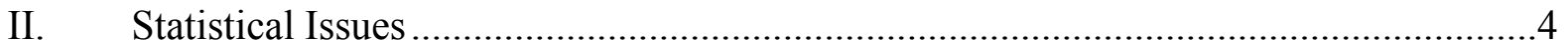




\section{ANNEX I. LUXEMBOURG: FUND RELATIONS}

(As of April 30, 2010)

Mission: April 7-19, 2010. The concluding statement of the mission is available at http://www.imf.org/external/np/ms/2010/041910.htm.

Staff team: Messrs. Hoffmaister (Head), Vázquez and Vacher (all EUR).

Country interlocutors included: Mr. Yves Mersch, Governor, Central Bank of Luxembourg; Mr. Jeannot Krecké, Minister of the Economy and Foreign Trade; Mr. Georges Heinrich, Director of Treasury; Dr. Serge Allegrezza, Director, Statec; Mr. Jean Guill, General Director, Financial Sector Supervisory Commission. Mr. Dirk Mevis, IMF Advisor to the Executive Director also participated in the discussions. Outreach activities included meetings with trade unions and a press conference.

Fund relations: The previous Article IV consultation took place on March 19-31, 2009 (IMF Country Report No. 09/178). The staff report and associated Executive Board's assessment are available at: http:/www.imf.org/external/pubs/ft/scr/2009/cr09178.pdf.

Data: Luxembourg subscribes to the Fund's Special Data Dissemination Standard, and data provision is adequate for surveillance (Annex II).

I. Membership Status: Joined: December 27, 1945; Article VIII

II. General Resources Account:

Quota

Fund Holdings of Currency

Reserve position in Fund

III. SDR Department:

Net Cumulative Allocation

Holdings
SDR Million

279.10

227.03

52.10

SDR Million

246.62

243.25
Percent Quota

100.00

81.34

18.67

Percent Allocation

100.00

98.63

IV. Outstanding Purchases and Loans: None

V. Financial Arrangements: None 
VI. Projected Payments to the Fund (SDR million; based on existing use of resources and present holdings of SDRs):

\begin{tabular}{lccccc} 
& \multicolumn{5}{c}{ Forthcoming } \\
\cline { 2 - 6 } $\begin{array}{l}\text { Principal } \\
\text { Charges/Interest } \\
\text { Total }\end{array}$ & $\underline{\mathbf{2 0 1 0}}$ & $\mathbf{2 0 1 1}$ & $\mathbf{2 0 1 2}$ & $\mathbf{2 0 1 3}$ & $\mathbf{2 0 1 4}$ \\
& 0.01 & $\underline{0.01}$ & $\underline{0.01}$ & $\underline{0.01}$ & $\underline{0.01}$ \\
& & & & &
\end{tabular}

\section{Exchange Rate Arrangement:}

Luxembourg's currency is the euro, which floats freely and independently against other currencies. Luxembourg has accepted the obligations of Article VIII, Sections 2, 3, and 4 , and maintains an exchange system free of restrictions on payments and transfers for current international transactions, other than restrictions notified to the Fund under Decision No. $144(52 / 51)$.

\section{Anti-Money Laundering/Combating the Financing of Terrorism (AML/CFT):}

The framework is based on the Law of 17 July 2008 (transposing the 3rd EU AML/CFT Directive into the Luxembourg legal system), the Law of 12 November 2004 (Law on the Prevention of Money Laundering and Terrorist Financing), the criminal code, relevant EU legislation, regulations by the government, and guidelines issued by the CSSF. In May 2009, the FATF evaluated Luxembourg's AML/CFT framework and its compliance with the 49+ recommendations of the FATF. The Report, published in February 2010, describes and analyses the AML/CFT situation in Luxembourg at the time of the on-site visit (May 2009) and offers recommendations on how to strengthen certain aspects of the system. It also assesses Luxembourg's level of compliance with the FATF 40+9 Recommendations. As a first step in the incorporation of the FATF's recommendations, Luxembourg's parliament adopted a law establishing criminal liability for legal persons in February 2010; the government also implemented regulations amending the law on the prevention of money laundering and terrorist financing and transposing guidelines that the CSSF had issued to credit institutions. 


\section{ANNEX II. LUXEMBOURG: STATISTICAL ISSUES}

(As of April 23, 2010)

\section{Assessment of Data Adequacy for Surveillance}

General: Data provision is adequate for surveillance. The Central Service for Statistics and Economic Studies (Statec) regularly publishes a full range of economic and financial data and provides an advance release calendar for main statistical releases at: http://www.statistiques.public.lu/fr/calendrier/index.html.

On-line access to Statec's databases and those of other jurisdictions is available to all users simultaneously at the time of release through the Statistics Portal of Luxembourg.

Key publicly accessible websites for macroeconomic data and analysis are:

Statistics Portal of Luxembourg. http://www.statistiques.public.lu/fr/

Statec .http://www.statec.public.lu/fr/index.html

Central Bank of Luxembourg .http://www.bcl.lu/en/index.php Ministry of Finance. http://www.mf.public.lu/

National Accounts: Luxembourg avails itself of the SDDS special flexibility for the timeliness of the national accounts, and generally disseminates national accounts data not later than four months after the reference period (the SDDS timeliness requirement for the national accounts is three months). Reduction of the reporting lag would aid surveillance.

\section{Data Standards and Quality}

Subscriber to the Fund's Special Data No data ROSC is available.

Dissemination Standard (SDDS) since May 12, 2006. Uses SDDS flexibility options on the timeliness of national accounts and analytical accounts of the central bank. 


\section{LUXEMBOURG: TABLE OF COMMON INDICATORS REQUIRED FOR SURVEILLANCE}

(As of April 23, 2010)

\begin{tabular}{|c|c|c|c|c|c|}
\hline & $\begin{array}{c}\text { Date of } \\
\text { Latest } \\
\text { Observation } \\
\end{array}$ & $\begin{array}{l}\text { Date } \\
\text { Received }\end{array}$ & $\begin{array}{c}\text { Frequency } \\
\text { of } \\
\text { Data }^{7}\end{array}$ & $\begin{array}{l}\text { Frequency } \\
\text { of } \\
\text { Reporting }^{7}\end{array}$ & $\begin{array}{l}\text { Frequency } \\
\quad \text { of } \\
\text { Publication }^{7}\end{array}$ \\
\hline Exchange Rates & $04 / 21 / 10$ & $04 / 21 / 10$ & $\mathrm{D}$ & $\mathrm{D}$ & $\mathrm{D}$ \\
\hline $\begin{array}{l}\text { International Reserve Assets and } \\
\text { Reserve Liabilities of the Monetary } \\
\text { Authorities }{ }^{1}\end{array}$ & March 2010 & $04 / 30 / 10$ & $\mathrm{M}$ & M & M \\
\hline Reserve/Base Money & March 2010 & $04 / 30 / 10$ & $\mathrm{M}$ & M & M \\
\hline Broad Money & March 2010 & $04 / 30 / 10$ & $\mathrm{M}$ & M & M \\
\hline Central Bank Balance Sheet & March 2010 & $04 / 30 / 10$ & $\mathrm{M}$ & M & M \\
\hline $\begin{array}{l}\text { Consolidated Balance Sheet of the } \\
\text { Banking System }\end{array}$ & March 2010 & $04 / 30 / 10$ & $\mathrm{M}$ & M & M \\
\hline Interest Rates ${ }^{2}$ & $04 / 21 / 10$ & $04 / 21 / 10$ & $\mathrm{D}$ & $\mathrm{D}$ & $\mathrm{D}$ \\
\hline Consumer Price Index & March 2010 & $04 / 07 / 10$ & M & M & M \\
\hline $\begin{array}{l}\text { Revenue, Expenditure, Balance and } \\
\text { Composition of Financing }{ }^{3}-\text { General } \\
\text { Government }\end{array}$ & 2009 Q2 & $12 / 30 / 2009$ & Q & Q & Q \\
\hline $\begin{array}{l}\text { Revenue, Expenditure, Balance and } \\
\text { Composition of Financing }{ }^{3}-\text { Central } \\
\text { Government }\end{array}$ & 2009 Q4 & $04 / 01 / 10$ & Q & Q & Q \\
\hline $\begin{array}{l}\text { Stocks of Central Government and } \\
\text { Central Government-Guaranteed Debt }\end{array}$ & 2009 Q4 & $04 / 01 / 10$ & Q & Q & Q \\
\hline External Current Account Balance & 2009 Q4 & $03 / 30 / 10$ & Q & Q & Q \\
\hline $\begin{array}{l}\text { Exports and Imports of Goods and } \\
\text { Services }\end{array}$ & $\begin{array}{l}\text { February } \\
2010\end{array}$ & $04 / 23 / 10$ & M & M & M \\
\hline GDP/GNP & 2009 Q4 & $04 / 06 / 10$ & Q & Q & Q \\
\hline Gross External Debt & 2009 Q4 & $04 / 06 / 10$ & Q & Q & Q \\
\hline International Investment Position ${ }^{6}$ & 2009 Q4 & $03 / 30 / 10$ & Q & $\mathrm{Q}$ & Q \\
\hline
\end{tabular}

${ }^{1}$ Including reserve assets that are pledged or otherwise encumbered.

${ }^{2}$ Both market-based and officially-determined, including discount rates, money market rates, rates on treasury bills, notes and bonds.

${ }^{3}$ Foreign, domestic bank, and domestic nonbank financing.

${ }^{4}$ The general government consists of the central government (budgetary funds, extra budgetary funds, and social security funds) and state and local governments.

${ }^{5}$ Including currency and maturity composition.

${ }^{6}$ Includes external gross financial asset and liability positions vis-à-vis nonresidents.

${ }^{7}$ Daily (D); weekly (W); monthly (M); quarterly (Q); annually (A); irregular (I); and not available (NA). 


\section{INTERNATIONAL MONETARY FUND}

EXTERNAL

RELATIONS

Public Information Notice

DEPARTMENT

Public Information Notice (PIN) No. 10/70

FOR IMMEDIATE RELEASE

June 3, 2010
International Monetary Fund

$70019^{\text {th }}$ Street, NW

Washington, D. C. 20431 USA

\section{IMF Executive Board Concludes 2010 Article IV Consultation with Luxembourg}

On May 28, 2010, the Executive Board of the International Monetary Fund (IMF) concluded the Article IV consultation with Luxembourg. ${ }^{1}$

\section{Background}

The global financial crisis posed a severe shock to Luxembourg's exceptionally open economy and internationally-integrated financial center. Private investment plummeted and consumption weakened in the face of slowing employment growth. At the height of the financial turmoil, the investment fund industry endured large redemptions, two systemically important banks were bailed out, and three smaller Icelandic banks failed. As a result, Luxembourg's economy contracted by $3 \frac{1}{2}$ percent in 2009 , its worst performance in 30 years.

Still, a prompt and aggressive policy response safeguarded financial stability and mitigated adverse economic effects. The authorities' decisive action in tackling troubled banks, combined with increases in deposit guarantees and substantial emergency liquidity provided by the European Central Bank (ECB), helped ameliorate financial contagion and

\footnotetext{
${ }^{1}$ Under Article IV of the IMF's Articles of Agreement, the IMF holds bilateral discussions with members, usually every year. A staff team visits the country, collects economic and financial information, and discusses with officials the country's economic developments and policies. On return to headquarters, the staff prepares a report, which forms the basis for discussion by the Executive Board. At the conclusion of the discussion, the Managing Director, as Chairman of the Board, summarizes the views of Executive Directors, and this summary is transmitted to the country's authorities. An explanation of any qualifiers used in summings up can be found here: http://www.imf.org/external/np/sec/misc/qualifiers.htm
} 
restore market confidence. In addition, Luxembourg's enviable position of public finances at the outset of the crisis provided the space to provide fiscal support to the economy, boost social transfers, and protect household income.

Systemic financial stability risks have receded in line with international developments, but growth will remain below its pre-crisis pace in 2010-11. Economic activity rebounded in the second half of 2009 led by the manufacturing and financial sectors, and labor markets showed initial signs of stabilizing. Net inflows to the investment fund industry resumed in the second quarter of 2009 with assets rebounding to close to their pre-crisis highs. Emergency liquidity provision has continued unwinding in an orderly manner and no bank failures occurred in 2009. The global financial crisis, nonetheless, is likely to have lasting effects on Luxembourg's economy. Growth is predicted to reach about 3 percent in 2010, reflecting improving conditions in global financial markets and trading partners as well as sustained fiscal stimulus. Inflation is expected to remain subdued.

\section{Executive Board Assessment}

Executive Directors noted that Luxembourg, with its open economy and large internationally-integrated financial sector, experienced a severe shock from the global financial crisis. They commended the authorities' prompt and forceful policy response, which safeguarded the financial sector. At the same time, Luxembourg's strong fiscal position provided room for fiscal policy to support the economy and protect household incomes. While the economy has stabilized and growth has resumed, the balance of risks remains on the downside. Directors encouraged the authorities to address the vulnerabilities exposed by the crisis.

Directors welcomed the strengthening of banking supervision and increasing emphasis on the quality of banks' risk management practices. They recommended a sharper focus on liquidity and credit risks arising from banks' sizable and concentrated exposures to their foreign parent groups. They highlighted the importance of ensuring that locally-incorporated subsidiaries maintain adequate capital and liquidity buffers. Directors welcomed the joint collaboration between the central bank and the banking supervisor in assessing and monitoring liquidity risks, and encouraged the authorities to establish a formal agreement to support this undertaking.

In light of the prevalence of foreign subsidiaries in Luxembourg's banking system, Directors encouraged the authorities to remain actively engaged in EU initiatives on the design of formal mechanisms for cross-border bank resolution and burden sharing. They recognized that long-standing collaboration between local and home country supervisors facilitated the response to the crisis, and recommended further enhancing this collaboration. Directors looked forward to timely implementation of the FATF recommendations. 
While agreeing that fiscal support continues to be appropriate in 2010, Directors advised the authorities to start consolidation in 2011 and target a balance by 2014 as planned. They welcomed the announced consolidation measures for 2011-12 as broadly appropriate. A few Directors considered that additional adjustment might be needed to achieve fiscal balance. With the need to center consolidation on current expenditure, a medium-term fiscal framework would be important to facilitate expenditure review and prioritization. Directors emphasized that the sustainability of public finances will require substantive pension reform, including a gradual increase in the effective and statutory retirement age and aligning benefits and contributions.

Directors considered that Luxembourg's economic resilience will depend on continued efforts to boost competitiveness and foster economic diversification. They welcomed the authorities' intention to revise the backward-looking wage indexation mechanism, and called for further reforms to eliminate wage-setting rigidities over time. Investment in skills development and in research will be important.

Public Information Notices (PINs) form part of the IMF's efforts to promote transparency of the IMF's views and analysis of economic developments and policies. With the consent of the country (or countries) concerned, PINs are issued after Executive Board discussions of Article IV consultations with member countries, of its surveillance of developments at the regional level, of post-program monitoring, and of ex post assessments of member countries with longer-term program engagements. PINs are also issued after Executive Board discussions of general policy matters, unless otherwise decided by the Executive Board in a particular case. The staff report (use the free Adobe Acrobat Reader to view this pdf file) for the 2010 Article IV Consultation with Luxembourg is also available. 
Luxembourg: Selected Economic Indicators

\begin{tabular}{|c|c|c|c|c|c|}
\hline & 2006 & 2007 & 2008 & 2009 & $\begin{array}{r}20101 / \\
\text { Proj. }\end{array}$ \\
\hline Real economy & \multicolumn{5}{|c|}{ (Change in percent, unless otherwise indicated) } \\
\hline Real GDP & 5.6 & 6.5 & 0 & -3.4 & 3 \\
\hline Gross fixed investment & 4.7 & 12.6 & -0.1 & -3.3 & -1.5 \\
\hline Unemployment (as percent of the labor force) & 4.5 & 4.4 & 4.4 & 7.1 & 6.4 \\
\hline Resident employment (thousands) & 203.1 & 207.7 & 213.3 & 210.5 & 215.3 \\
\hline Total employment (thousands) & 319 & 333.2 & 348.7 & 341.8 & 348 \\
\hline CPI (harmonized), p.a. & 2.3 & 2.2 & 2.3 & 2.5 & 2.6 \\
\hline Public finances & \multicolumn{5}{|c|}{ (Percent of GDP) } \\
\hline General government revenues & 39.7 & 39.8 & 40.1 & 41.6 & 37.7 \\
\hline General government expenditures & 38.3 & 36.2 & 37.2 & 42.4 & 41.4 \\
\hline General government balance & 1.4 & 3.6 & 2.9 & -0.7 & -3.7 \\
\hline General government gross debt & 6.5 & 6.7 & 13.7 & 16.4 & 19.6 \\
\hline Balance of payments & & & & & \\
\hline Current account balance & 10.3 & 9.7 & 5.3 & 5.6 & 5.5 \\
\hline Balance of trade in goods and services & 38.6 & 44.3 & 40.8 & 39.7 & 33.4 \\
\hline Factor income balance & -25.6 & -30.3 & -30.8 & -31.3 & -23.7 \\
\hline Transfer balance & -2.7 & -4.3 & -4.7 & -2.7 & -4.2 \\
\hline Exchange rates & \multicolumn{5}{|c|}{ Member of the euro area } \\
\hline U.S. dollar per euro & 1.3 & 1.4 & 1.5 & 1.4 & 1.4 \\
\hline Nominal effective rate $(2005=100)$ & 100.2 & 101.5 & 103 & 103.1 & 102.3 \\
\hline
\end{tabular}

Sources: Data provided by the authorities; and IMF staff calculations and projections.

$1 /$ Staff projections, if not otherwise indicated. 


\section{Statement by Johann Prader, Alternate Executive Director for Luxembourg and Dirk Mevis, Advisor to the Executive Director \\ May 28, 2010}

On behalf of the Luxembourg authorities, we would like to thank staff for the well-written and insightful report that provides a thorough and objective view of the macro-economic situation in Luxembourg and the challenges the economy is facing. The policy dialogue has been fruitful and the authorities broadly share the views of the staff.

\section{Recent Developments and Outlook}

The Luxembourg economy is recovering after a severe downturn caused by the global economic and financial crisis. GDP growth has strongly rebounded in the third quarter of 2009 and remained stable in the fourth quarter. This has resulted in positive growth of 1.4 percent y-o-y in 2009/Q4. GDP for the year as a whole has contracted by 3.4 percent which is still slightly better than projected. The statistical office of Luxembourg currently predicts growth for 2010 at 2.5 percent and for 2011 at 3 percent.

The two sectors most affected by the downturn were industrial production, contributing about half of the contraction, and the financial sector, accounting for roughly one third of the reduction in GDP. Industrial production declined by 16.3 percent but due to the extension of partial employment schemes by the government, this sector only shed 2.5 percent of its labor force. Looking ahead, survey based indicators have revealed renewed optimism in this sector over the past months. In line with developments in the global financial markets, the financial sector has turned around in 2009/Q3, growing by 2.6 percent (q-o-q), and has subsequently stabilized in Q4, growing by 0.9 percent (q-o-q). Services to enterprises followed the financial sector with positive developments in the second half of 2009. Due to developments in oil prices, retail prices and utility tariffs, headline inflation has picked up in March and April 2010 and has reached 2.3 percent.

\section{The Financial Sector and Developments in Supervision}

The financial sector has stabilized and is being prepared for the challenges of the future. The authorities' immediate stabilization measures in the cases of Fortis and Dexia have fostered confidence in the Luxembourg financial center and its prudential framework. The collapse of the subsidiaries of the three Icelandic banks has put the Luxembourgish deposit guarantee scheme to the test. The scheme, which prior to the crisis was funded on an ex-post basis, honored the demands of depositors without any difficulties as provisions of Euro 828 million had been accumulated and about Euro 300 million were paid out. A draft law for an ex-ante funded deposit insurance scheme - including the possibility of early resolutions on a least-cost principle - has been prepared and the authorities are currently 
awaiting the issuance by the European Commission of principles for deposit insurance schemes before finalizing the draft law and submitting it to parliament.

Nevertheless, the financial sector has been deeply affected by the crisis and conclusions from the crisis will shape the future prudential and supervisory framework of the

financial center. Banking sector assets have declined by 14.74 percent from December 2008 to December 2009 - mostly due to a decrease in interbank lending. Deleveraging went in parallel with a strengthening in Tier I capital by 11 percent on average and a reduction in the average leverage ratio of 1 percent. The solvency ratio of 96.3 percent of Luxembourg banks is above 10 percent and the average solvency ratio has increased by 3.24 percent during 2009. Employment in the banking sector declined by 2.9 percent between December 2008 and December 2009 and is expected to decline further due to additional deleveraging, consolidation and rationalization in the banking sector. Investment fund assets dropped by roughly Euro 560 billion from their peak in October 2007 but have recovered in the second half of 2009 to pre-crisis levels. The Luxembourg subsidiaries of foreign banks were rather well positioned at the outset of the crisis and difficulties emerged only following adverse spillover effects related to events in parent banks.

Supervision is one of the cornerstones for the development of an international financial center such as Luxembourg and has been strengthened considerably over the past year. The recent FATF report has given a new impetus to the authorities to further strengthen both the efficiency of the system as well as the means and resources available to the authorities to fight money laundering in Luxembourg. The Commission de Surveillance du Secteur Financier (CSSF) has strengthened its staff and further enhanced its supervisory framework while the Banque Centrale du Luxembourg (BCL) has created two special units, thereby completing the Luxembourg financial supervisory landscape. Discussions on a formalization of the cooperation between the CSSF and the BCL are ongoing. Cooperation on an informal level is already extensive, including through joint on-site inspections and exchange of information. The authorities are looking forward to the upcoming FSAP at the end of 2010.

Over the past year, the CSSF has implemented its enhanced supervisory review process. All banks are subject to a comprehensive risk assessment (at least) once a year, which is also made available to home supervisors, especially in the context of joint colleges. The assessment, supported by an internal rating system, is complemented by a capital-add-on policy. Over the past year, the CSSF started to make use of this capital add-on policy and called on four banks to hold capital above the Basel II minimum requirements following the results of CSSF stress tests. Furthermore, the CSSF has intensified its dialogue with banks with respect to risk management at large and liquidity risk management in particular. In the context of its "supervisory review process", the CSSF has had and extensive exchange of views with the local risk management of 1/5 of all Luxembourg banks (representing 55 percent of total assets) over the last year. The focus lay with the risk identification process and the CSSF found scope for substantial enhancement and required corresponding changes 
in the banks' ICAAPs. Finally, as a result of closer monitoring and increased intervention in banks' business models, the CSSF has acted a number of times in 2009 in order to limit excessive sovereign risk concentrations in the context of rising levels of public debt and the corresponding deterioration of creditworthiness.

Similarly, the BCL has vastly expanded its supervisory activities with one unit located in the Financial Supervisory Department, in charge of monitoring liquidity at the institutional level and the Financial Stability and Risk Management unit tackling the macro-prudential aspects and assessing systemic liquidity risk. The BCL liquidity monitoring framework at the institutional level comprises qualitative and forward-looking quantitative analysis and includes both off-site analysis and on-site visits. According to market and funding liquidity stress-testing performed at the BCL, Luxembourg's systemic liquidity risk remains low even if confronted with an interbank market shock. With regard to capital adequacy, stress testing done at the BCL shows that Luxembourg banks have a tier 1 capital ratio level sufficient to withstand, in aggregate and individually, a sizable and plausible negative shock to Luxembourg or EU real GDP, a sizable increase in real interest rates or a sizable fall in real property prices. The capital ratio remains sufficient under all scenarios.

Changes in bank reporting are being implemented to better measure the maturity structure of banks' balance sheets. The BCL now requires major banks to provide liquidity gap projections on a daily basis.

The Luxembourg authorities welcome enhanced international cooperation and coordination of financial supervision and continue to engage intensively with home country supervisors. From a regulatory viewpoint, the country is engaged in and fully supports international discussions regarding liquidity standards, new definitions of capital and a leverage ratio in the context of pending reforms at the level of CEBS ${ }^{1}$ and $\mathrm{BCBS}^{2}$. The CSSF also has a long-standing history of home-host cooperation in the context of supervisory colleges for systemic banking groups and is preparing for the significant increase in the number of these colleges in the near future. Furthermore, the CSSF and BCL are engaging intensively with banks to prepare them for potential future changes in regulation. Regarding liquidity, the CSSF and the BCL have issued regulations requiring banks to incorporate the CEBS recommendations on sound liquidity management.

\section{Fiscal Consolidation and other issues}

The government set out on a path of thorough consolidation to put fiscal policy on a sustainable footing. Luxembourg has a tradition of social consensus in policy making which

\footnotetext{
${ }^{1}$ Committee of European Banking Supervisors

${ }^{2}$ Basel Committee on Banking Supervision
} 
is reflected in the tripartite discussion between trade-unions, employers and the government. These discussions usually set the stage for all reforms with an important social impact. In this context, the tripartite has discussed in April 2010 the consolidation path outlined in the government's Stability and Growth Programme with a view to identifying the necessary fiscal consolidation measures underpinning the consolidation path. In early May, the Prime Minister announced a fiscal consolidation package for 2011 and 2012 which aims to reduce expenditures and increase revenues by Euro 655.9 million in 2011 and Euro 717.5 million in 2012 (equals about 1.7 percent of GDP each year) relative to a scenario of "unchanged policies". These consolidation measures include structural changes in social transfers and a hiring freeze in the public sector together with a cap on public investment. The share of expenditure cuts is about $2 / 3$ of the total package. In 2012, based on an assessment of the economic and budgetary situation, further measures will be considered in the context of the medium term goal of a balanced budget for 2014. In addition, the government intends to reform remuneration in the public sector. The proposals put forward entail a temporary freeze of real wages and modifications to the wage structure in general. Discussions with the public sector trade-union are ongoing and results are expected soon.

The authorities are keen to move to a more forward-looking budgetary framework. While currently the Stability and Growth Programme serves as a forward-looking tool of budgetary management, the authorities are reviewing the options for a more systematic expenditure framework that should be oriented on the medium term.

Social security systems need to be adapted to deal with the challenge posed by population ageing and technical progress in the health sector. A technical working group of tripartite composition has analyzed the situation and taken stock of the issues at hand. On the basis of a report prepared by this working group, the Minister for Social Security has identified the main parameters to be adjusted as part of a comprehensive reform of the pension system. In the fall of 2010, the government will discuss these proposals with the social partners. These discussions will form the basis for an effective reform which will put the pension system on a more sustainable footing. Furthermore, structural problems in the universal medical insurance are to be addressed in discussions with social partners in the second half of 2010 .

Competitiveness is currently one of the top priorities of the Luxembourg authorities. In order to counter a worsening in competitiveness through rising unit labor costs, further discussions are scheduled to take place in the fall. Discussions will also pertain to the automatic indexation mechanism. Recent proposals to adapt the mechanism center around the exclusion of goods with high price volatility and other modifications that would ease the pressure of the mechanism on wages. 